\title{
Assessment of High Rates of Precocious Male Maturation in a Spring Chinook Salmon Supplementation Hatchery Program
}

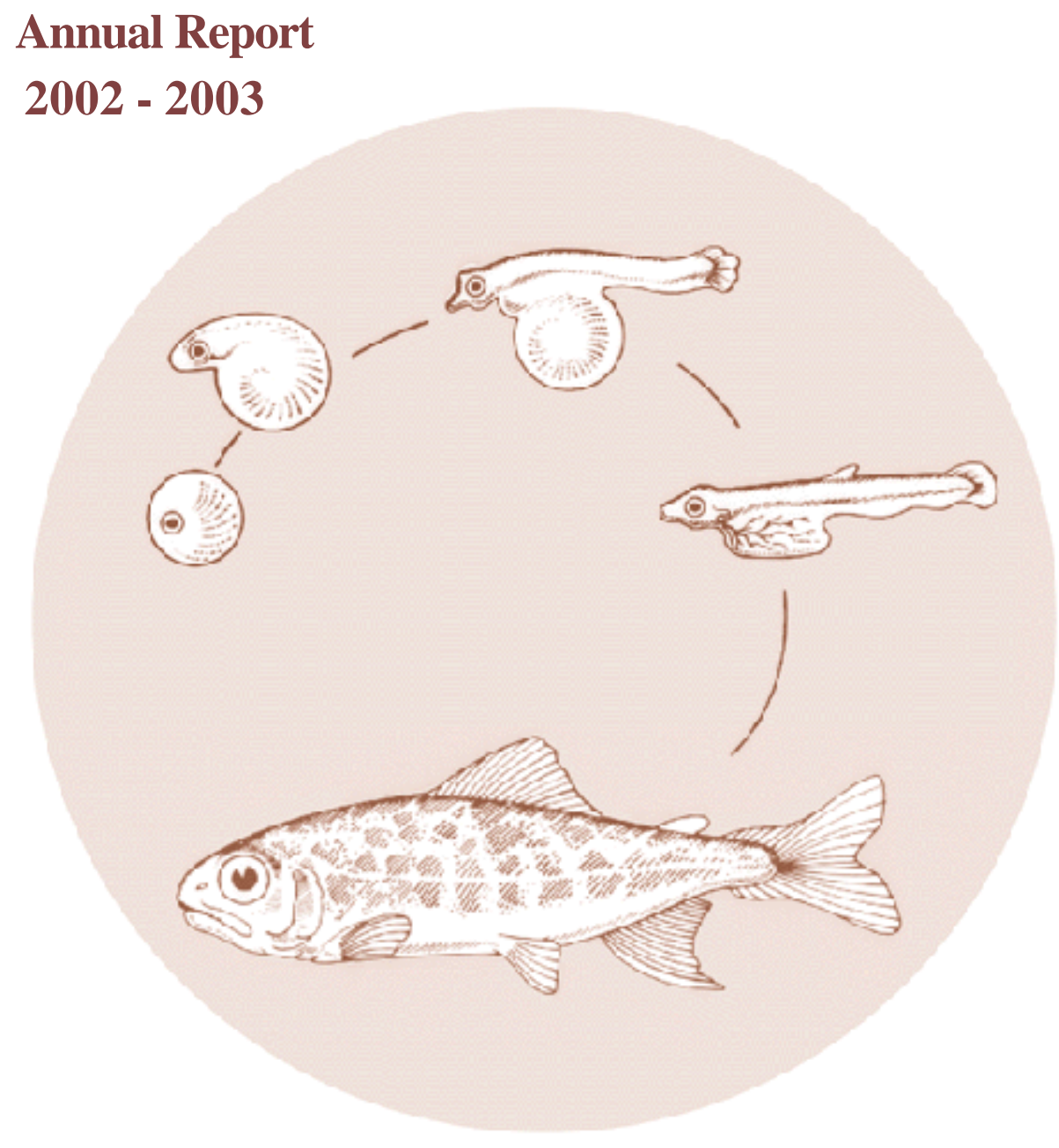

DOE/BP-00009556-1

August 2003 
This Document should be cited as follows:

Larsen, Donald, Brian Beckman, Kathleen Cooper, Dan Barrett, Mark Johnston, Penny Swanson, Walton Dickhoff, "Assessment of High Rates of Precocious Male Maturation in a Spring Chinook Salmon Supplementation Hatchery Program", Project No. 2002-03100, 39 electronic pages, (BPA Report DOE/BP-00009556-1)

Bonneville Power Administration

P.O. Box 3621

Portland, Oregon 97208

This report was funded by the Bonneville Power Administration (BPA), U.S. Department of Energy, as part of BPA's program to protect, mitigate, and enhance fish and wildlife affected by the development and operation of hydroelectric facilities on the Columbia River and its tributaries. The views in this report are the author's and do not necessarily represent the views of BPA. 


\title{
Assessment of High Rates of Precocious Male Maturation in a Spring Chinook Salmon Supplementation Hatchery Program
}

\author{
Donald A. Larsen ${ }^{1}$, Brian R. Beckman ${ }^{1}$, Kathleen A. Cooper ${ }^{2}$, Dan Barrett ${ }^{3}$, Mark \\ Johnston ${ }^{4}$, Penny Swanson ${ }^{1}$, and Walton W. Dickhoff ${ }^{1,2}$
}

\section{Annual Report 2003}

Project Number 2002-031-00

August 2003

\footnotetext{
${ }^{1}$ Integrative Fish Biology Program Northwest Fisheries Science Center, National Marine Fisheries Service, 2725 Montlake Blvd. E. Seattle, Washington 98112, USA

${ }^{2}$ School of Aquatic and Fisheries Science, University of Washington, Seattle, Washington 98195, USA

${ }^{3}$ Cle Elum Supplementation and Research Facility, Yakama Nation, 800 Spring Chinook Way, Cle Elum, Washington 98922

${ }^{4}$ Yakama Nation, Nelson Springs Research Center, 771 Pence Road, Yakima, Washington
}

Disclaimer: Use of trade names does not imply endorsement by the National Marine Fisheries Service, NOAA. 


\section{SUMMARY}

The Yakima River Spring Chinook Salmon Supplementation Project in Washington State is currently one of the most ambitious efforts to enhance a natural salmon population in the United States. Over the past five years we have conducted research to characterize the developmental physiology of naturally- and hatchery-reared wild progeny spring chinook salmon (Oncorhynchus tshawytscha) in the Yakima River basin. Fish were sampled at the main hatchery in Cle Elum, at remote acclimation sites and, during smolt migration, at downstream dams. Throughout these studies the maturational state of all fish was characterized using combinations of visual and histological analysis of testes, gonadosomatic index (GSI), and measurement of plasma 11-ketotestosterone (11-KT). We established that a plasma $11-\mathrm{KT}$ threshold of $0.8 \mathrm{ng} / \mathrm{ml}$ could be used to designate male fish as either immature or precociously maturing approximately 8 months prior to final maturation (1-2 months prior to release as "smolts"). Our analyses revealed that $37-49 \%$ of the hatchery-reared males from this program undergo precocious maturation at 2 years of age and a proportion of these fish appear to residualize in the upper Yakima River basin throughout the summer. An unnaturally high incidence of precocious male maturation may result in loss of potential returning anadromous adults, skewing of female: male sex ratios, ecological, and genetic impacts on wild populations and other native species. Precocious male maturation is significantly influenced by growth rate at specific times of year and future studies will be conducted to alter maturation rates through seasonal growth rate manipulations. 


\section{TABLE OF CONTENTS}

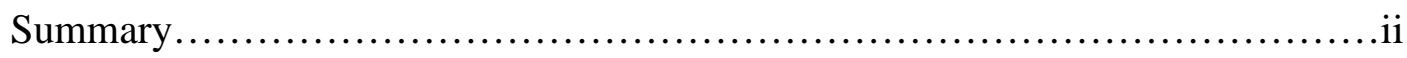

Table of Contents........................................................ ii

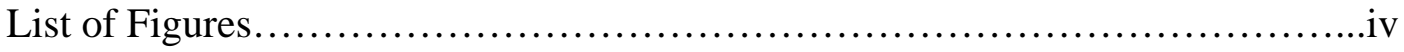

List of Tables............................................................vi

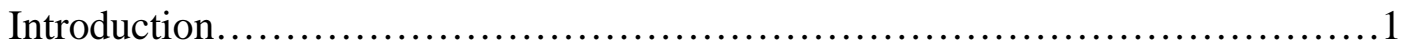

Methods....................................................................

Results.............................................................

Discussion............................................................... 19

Acknowledgements.................................................... 25

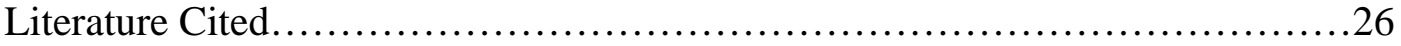




\section{LIST OF FIGURES}

Figure 1. Map of the Yakima River, Washington. Juvenile spring chinook salmon are reared at the Yakima Supplementation Research Facility in Cle Elum (Cle Elum Hatchery) then transferred in the spring to Easton, Jack Creek or Clark Flat acclimation sites. During outmigration fish are captured at Roza, Prosser, and John Day Dams.... .4

Figure 2. Frequency distribution of log transformed plasma 11-ketotestosterone levels in visually categorized immature males (a), precociously maturing males (b), and males of undetermined maturational state (c) during the BY99 Maturation Screening on 14 March, 2000. Dashed line indicates midpoint of $0.8 \mathrm{ng} / \mathrm{ml}$ between frequency distributions of immature and maturing fish.........................................

Figure 3. Frequency distributions of log transformed plasma 11-ketotestosterone (a) and gonadosomatic index (b) of male fish from the BY 00 Maturity Screening on 15 March 2002 and the regression between log 11-KT and log GSI (c). Dashed lines indicate 11-KT midpoint of $0.8 \mathrm{ng} / \mathrm{ml}$ and GSI midpoint of 0.06. Regression Equation: $\mathrm{Y}$ $=0.415 \mathrm{x}-1.125, \mathrm{R}^{2}=0.7, \mathrm{p}<0.0001$

Figure 4. Frequency distributions of cumulative log transformed plasma 11ketotestosterone levels in BY98 hatchery male fish sampled over several dates at Cle Elum Hatchery (a), Jack Creek and Clark Flat Acclimation sites before (b) and after (c) the start of volitional migration, hatchery and wild fish sampled at Roza (d) and Prosser Dams (e) on the Yakima River and John Day Dam on the Columbia River (f). The 0.8 $\mathrm{ng} / \mathrm{ml} 11-\mathrm{KT}$ threshold is indicated by a line on several graphs....................11

Figure 5. Frequency distributions of cumulative log transformed plasma 11ketotestosterone levels in BY99 hatchery male fish sampled over several dates at Cle Elum Hatchery (a), Jack Creek and Clark Flat Acclimation sites before (b) and after (c) the start of volitional migration, hatchery and wild fish sampled at Roza (d) and Prosser Dams (e) on the Yakima River and John Day Dam on the Columbia River (f). The 0.8 $\mathrm{ng} / \mathrm{ml} 11-\mathrm{KT}$ threshold is indicated by a line on several graphs...

Figure 6. Light micrographs of testicular sections stained with hematoxylin and eosin from spring chinook salmon at Cle Elum Hatchery and Jack Creek Acclimation site with low (a-e) and high (f-j) plasma 11-ketotestosterone levels from 1 January to 22 May 2000 (b and g are from BY 99 Maturity Screening on 14 March 2001). SG-A (Type A spermatogonia), SG-EB (Early Type B spermatogonia), SG-LB (Late Type B spermatogonia), SC (Spermatocytes), ST (Spermatids). Magnification 40X...........13

Figure 7. Light micrographs of testicular sections stained with hematoxylin and eosin from spring chinook salmon captured at Roza, Prosser, and John Day Dams that were visually assessed as immature (a-c) and precociously maturing (d-f). SG-A (Type A spermatogonia), SG-EB (Early Type B spermatogonia), SG-LB (Late Type B spermatogonia), SC (Spermatocytes), ST (Spermatids), SZ (Spermatozoa).

Magnification 40X 
Figure 8. $\quad$ Proportions of precociously maturing male and immature male and female hatchery fish sampled over several dates at the Cle Elum Hatchery (a), Jack Creek and Clark Flat Acclimation Sites before (b) and after (c) the start of volitional migration, and hatchery and wild fish sampled at Roza (d) and Prosser Dams (e) on the Yakima River, and John Day Dam on the Columbia River (c) during the BY 98 Physiological Monitoring. At the hatchery and acclimation sites all male fish with 11-ketotestosterone levels greater than $0.8 \mathrm{ng} / \mathrm{ml}$ were designated as precociously maturing. At the dams maturing males were designated based on visual and histological analysis. After 14 March fish were allowed to volitionally emigrate from acclimation sites. Number of fish sampled at each site/time period is indicated for each histogram ....................16

Figure 9. Proportions of precociously maturing male and immature male and female hatchery fish sampled over several dates at the Cle Elum Hatchery (a), Jack Creek and Clark Flat Acclimation Sites before (b) and after (c) the start of volitional migration, and hatchery and wild fish sampled at Roza (d) and Prosser Dams (e) on the Yakima River, and John Day Dam on the Columbia River (c) during the BY 99 Physiological Monitoring. At the hatchery and acclimation sites all male fish with 11-ketotestosterone levels greater than $0.8 \mathrm{ng} / \mathrm{ml}$ were designated as precociously maturing. At the dams maturing males were designated based on visual and histological analysis. After 14 March fish were allowed to volitionally emigrate from acclimation sites. Number of fish sampled at each site/time period is indicated for each histogram.....................17

Figure 10. Proportions of precociously maturing male and immature male and female hatchery fish sampled on 14 March during the BY99 Maturity Screening (a) and on 15 March during the BY 00 Maturity Screening (b) at Easton, Jack Creek, and Clark Flat Acclimation Sites. All male fish with 11-ketotestosterone levels greater than $0.8 \mathrm{ng} / \mathrm{ml}$ were designated as precociously maturing. $\mathrm{N}=358-360$ fish at each site................18

Figure 11. Comparison of body weight growth curves for BY 98 and BY 99 Yakima hatchery spring chinook and BY 93 wild Yakima River spring chinook (Beckman et al. 2000). Plot for growth in May for BY 93 wild fish and May to August for BY 98 and BY 99 Yakima hatchery fish was extrapolated from existing growth curves and drawn by

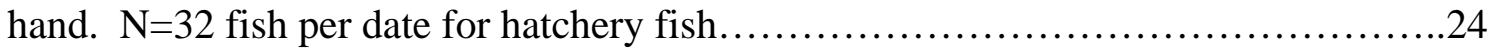




\section{LIST OF TABLES}

Table 1. Chi-squared analysis of pooled gender data from hatchery and wild brood year (BY) 98 and 99 fish collected at the Cle Elum Hatchery, Jack Creek and Clark Flat Acclimation Sites, Roza, Prosser and John Day Dams. Asterisk indicates significant difference of underlined vales from 50:50 male to female ratio, $\alpha=0.05 \ldots \ldots \ldots \ldots \ldots . .19$ 


\section{INTRODUCTION}

Throughout the Pacific Northwest of the United States salmon supplementation hatchery strategies are being employed in an attempt to rebuild natural spawning stocks and also augment fisheries. Successful supplementation relies on improving post release survival of hatchery salmon while reducing potential negative genetic and ecological impacts on wild fish. Although in practice definitions vary, a supplementation hatchery may be defined as a rearing facility to breed and propagate a stock of fish with equivalent genetic resources of the native stock, and with the full ability to return to reproduce naturally in its native habitat (Flagg and Nash 1999). These projects generally utilize production hatchery rearing methods with juvenile releases normally occurring at acclimation sites to provide homing to target areas. To minimize adverse genetic impacts in some programs, no returning hatchery adults are taken in to the hatchery as broodstock for subsequent generations; rather these fish are allowed to spawn naturally in the wild. Supplementation hatcheries have the potential benefits of reducing short-term risk of extinction, speeding recovery, reseeding vacant habitat, and increasing harvest opportunity. However, much controversy and uncertainty surrounds the use of these "experimental" facilities and, to date, little information is available regarding the performance of supplemented fish and their progeny in the natural environment.

The Yakima River Spring Chinook Salmon Supplementation Project in Washington State is one of the most ambitious tests, to date, of supplementation hatchery principles. Native spring chinook salmon (Oncorhynchus tshawytscha) broodstock are crossed according to strict genetics guidelines (Busack and Marshall 1991, Busack et al. 1997) to produce juveniles that are reared at the Cle Elum Supplementation Research Facility. In early spring of their second year the fish are moved to one of three remote acclimation sites in the upper Yakima River basin and reared to the time of parr-smolt transformation. All fish are differentially tagged according to raceway and acclimation site and allowed to volitionally emigrate in late spring from the headwaters of the Yakima River.

Our involvement in this project, to date, has centered on comparing and contrasting the physiological development of the first four brood years (1997-2000) of hatchery and wild Yakima River spring chinook to guide development of hatchery rearing protocols. This project provided a unique opportunity to make these comparisons in a stock of fish that had not previously experienced significant hatchery influences (Marshall et al. 1995, Myers et al. 1998). In the spring (March-May) of each year of this monitoring effort we noticed that between 9 and $70 \%$ (depending on date) of all hatchery fish sampled appeared to be undergoing yearling precocious male maturation at a time when the majority of the population typically undergoes the parr-smolt transformation.

Many species of anadromous male salmonids may undergo sexual maturation without migrating to salt water including masu salmon (O. masou) (Aida et al. 1984; Kato 1991), coho salmon (O. kisutch) (Iwamoto et al. 1984; Silverstein and Hershberger 1992); sockeye salmon, (O. nerka) (Ricker 1959); amago salmon (O. rhodurus) (Nagahama et al. 1982; Kato 1991); chinook salmon (O. tshawytscha) (Rich 1920; Gebhards 1960; Taylor 1989; Bernier et al. 1993; Unwin et al. 1999); steelhead trout $(O$. mykiss) (Schmidt and House 1979); Atlantic salmon (Salmo salar) (Myers et al. 1986); and sea trout (S. trutta) (Dellefors and Faremo 1988). Most of these fish are commonly 
referred to as "precocious" parr and typically mature after one or two (in some cases three) years in fresh water, and repeat maturation may occur among some species (Groot and Margolis, 1991; Thorpe and Morgan, 1980; Bernier et al. 1993; Clarke and Blackburn 1994; Unwin et al. 1999). The term "precocious maturation" could also be applied to "jacks" that are males that have gone to sea and returned to spawn at a younger age than females of their brood class. To avoid confusion, throughout this paper precocious maturation refers to male fish that mature toward the end of either their first year (sub-yearlings) or second year (yearlings) measured from the date of fertilization.

Precocious male maturation has been a topic of numerous basic and applied studies in Atlantic salmon (Myers 1984, 1986; Thorpe 1986; 1987; 1991; Hutching and Jones 1998) where rates are reported to range from 0 to $100 \%$ depending on the stock (Hutching and Jones 1998; Fleming 1998). In chinook salmon, this subject has received far less attention. Both sub-yearling and yearling precocious males exist in some spring chinook salmon populations (Robertson 1957; Gebhards 1960; Taylor 1989; Foote et al. 1991; Mullan et al 1992; Clarke and Blackburn; 1994; James et al 1998). The incidence of precocious maturation in wild stocks of spring chinook salmon is poorly characterized, but thought to be less than 5\% (Gebhards 1960; Mullan et al. 1992). In contrast, the proportion of males maturing as yearlings in some hatchery and experimental populations of spring chinook salmon ranges from 11 to 80\% (Foote et al. 1991; Mullan et al. 1992; Clarke and Blackburn 1994).

Age of maturation in salmon is influenced by genetic, biotic, and abiotic factors (Power 1986) including energy stores (whole body lipid), size and/or growth rate at specific times of year (Rowe et al. 1991; Hopkins and Unwin 1997; Silverstein et al. 1998; Shearer and Swanson 2000; Shearer et al. 2000, 2002). Studies in spring chinook salmon have shown that male maturation is physiologically initiated in the fall, approximately 10 months prior to autumn spawning (Silverstein et al. 1998; Shearer and Swanson, 2000; Shearer et al. 2000, 2002). External characteristics of maturation (olive pigmentation, deep body shape, and dark fin margins) as well as very large white gonads typical of the later stages of maturation may not be evident until mid-summer prior to autumn spawning. These obvious external signs of early maturity are often not seen in the hatchery since most spring chinook hatcheries release fish in March and April. This fact may explain, in part, why this issue has historically received only modest attention.

In this study we took a biochemical approach to early detection of precocious male maturation. The steroid, 11-ketotestosterone (11-KT), first isolated from sockeye salmon (O. nerka) by Idler et al. (1960), is the major male androgen in most teleost species (Borg, 1994) and typically increases in the plasma of male fish during reproductive maturation (Idler et al. 1971; Stuart-Kroger et al. 1981; Hunt et al. 1982; Schultz 1984; Mayer et al. 1990, 1992; Stead et al. 1999, Amer et al. 2001). Studies in the Japanese eel (Anguilla japonica) by Miura et al. (1994) and a salmonid, the Japanese huchen (Hucho perryi) by Amer et al. (2001) have demonstrated that 11-KT is necessary for the initiation of spermatogenesis and sperm production and probably has a role in spermiation as well.

This paper reports on the use of plasma 11-KT levels as well as gonadosomatic index (GSI), simple visual assessment, and histological examination of testes to differentiate between immature and maturing yearling spring chinook salmon at an early stage of development. These indices were used to estimate the rates of yearling male 
maturation in the Yakima Supplementation Program. Finally, we explore the management and ecological implications of these findings and discuss methodologies for controlling the incidence of yearling male maturation in hatchery programs.

\section{MATERIALS AND METHODS}

\section{Study Area and Hatchery Production}

The Yakima River Basin is located in central Washington State, USA with a total length of $349 \mathrm{~km}$ and a drainage area of $15,000 \mathrm{~km}^{2}$ (Figure 1). The basin contains three closely related, yet genetically distinct, subpopulations of wild spring chinook salmon: American River, Natches River and tributaries (excluding the American River), and Yakima River main stem and its tributaries (Busack and Marshall 1991; Myers et al. 1998).

The Yakima Supplementation Program began artificial production of spring chinook salmon in 1997 at the Cle Elum Supplementation Research Facility, Cle Elum, Washington (Berg 2001). Each year wild adult spring chinook salmon are randomly collected throughout the duration of the spawning migration at the Adult Collection and Monitoring Facility located at Roza Dam on the Yakima River (Rkm 208). Only wild fish are collected for the program and no more than $50 \%$ of the total wild run is taken for hatchery broodstock to insure that natural spawning always occurs in the river. Spawning occurs in September and early October (see Knudsen et al. 2002 for detailed description). Fry are ponded in April and reared in concrete raceways (30m length X 3 m width x $1 \mathrm{~m}$ depth), water flow - 2,200 l/min, density - 45,000 fish/raceway, and broadcast fed by hand or automatic belt feeder. The water source is a combination of Yakima River water and subsurface well water in seasonally varying proportions depending on ambient water temperature. Fish are fed Biodiet grower pellets (Bioproducts, Warrenton, OR) in rations determined by computer software designed by J. P. Lagasse (ODFW, Clackamas, OR) using target size-at-date, and seasonal water temperature data. Water temperature varies from $1^{\circ} \mathrm{C}$ in January-February to $15^{\circ} \mathrm{C}$ in late August. All hatchery fish are adipose fin clipped, receive coded-wire tags with codes specific to each raceway at each acclimation site, and are marked with visible implant fluorescent elastomer (VIE) eye tags (Northwest Marine Technologies Inc., Shaw Island, Washington) for visual identification at dams and on the spawning grounds. Furthermore, 5-10\% of all fish are tagged with passive integrative transponder (PIT) tags (Biomark Inc., Meridian, ID) to monitor migratory history of both juveniles and adults. Finally, each spring approximately 2,000-5,000 migrating wild Yakima River spring chinook are captured, PIT-tagged, and released at Roza Dam in order to compare their rate of migration and survival with that of the hatchery population.

In early February, fish are transported by tanker truck from the Cle Elum Hatchery to each of three remote acclimation sites (total 6 raceways/site) at Easton upstream of the Cle Elum Hatchery (Rkm 311), Jack Creek on the North Fork Teanaway River tributary (confluence with the Yakima River at Rkm 286) and Clark Flat downstream of the Cle Elum Hatchery ( $\mathrm{Rkm} 272$ ) (Figure 1). The rearing conditions at each of the remote acclimation sites are essentially identical with that of the Cle Elum 


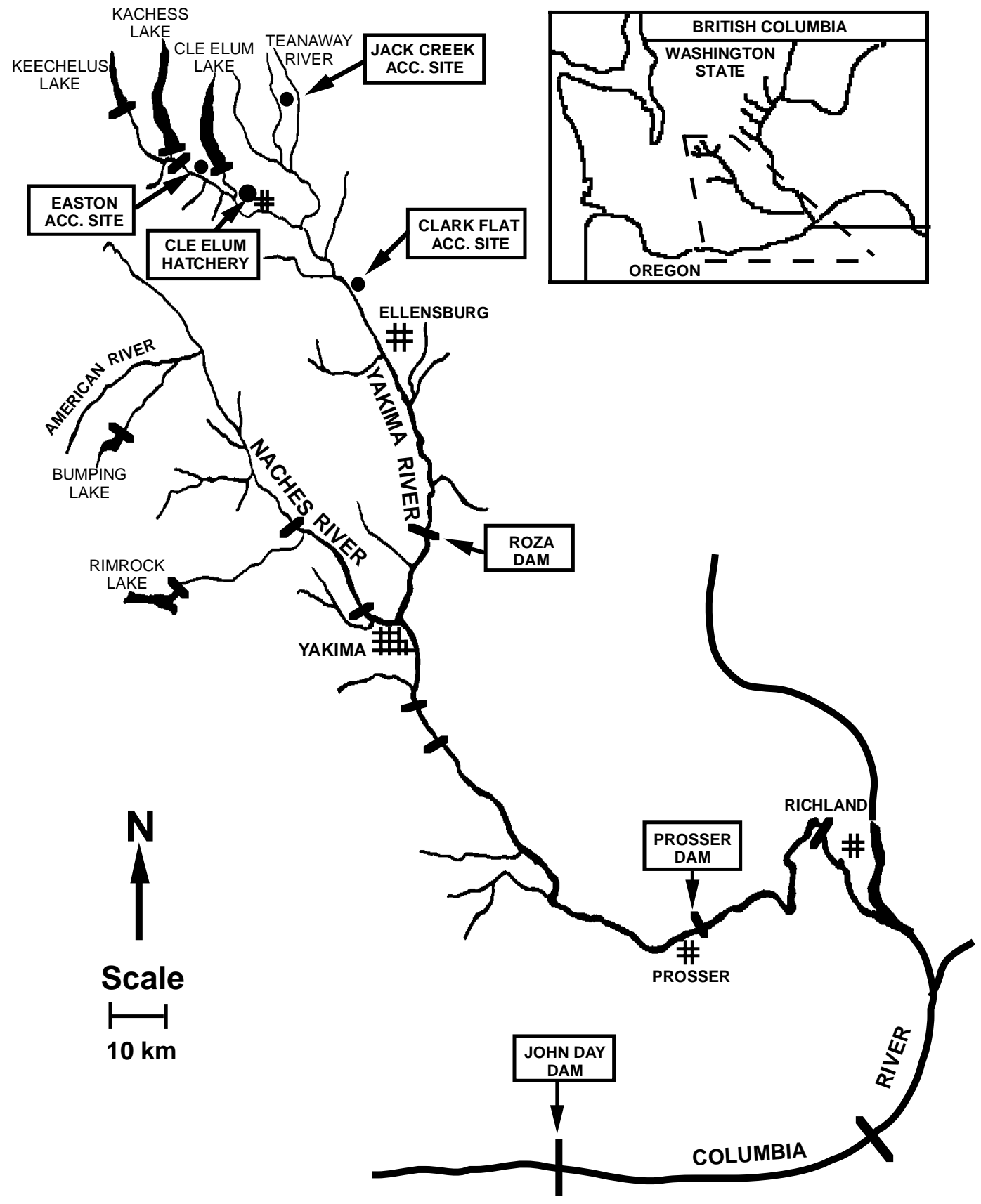

Figure 1. Map of the Yakima River, Washington. Juvenile spring chinook salmon are reared at the Yakima Supplementation Research Facility in Cle Elum (Cle Elum Hatchery) then transferred in the spring to Easton, Jack Creek or Clark Flat acclimation sites. During outmigration fish are captured at Roza, Prosser, and John Day Dams. 
Hatchery with the exceptions of water flow (lower at the acclimation sites) and the seasonal thermograph that varies with acclimation site location: temperatures at Jack Creek ranged from $1{ }^{\circ} \mathrm{C}$ in February to $6-8^{\circ} \mathrm{C}$ in May, at Easton from $3^{\circ} \mathrm{C}$ in February to $8^{\circ} \mathrm{C}$ in May, and at Clark Flat from $3^{\circ} \mathrm{C}$ in February to $10^{\circ} \mathrm{C}$ in May. At all acclimation sites surface river water is utilized.

In mid-March volitional migration of smolts is allowed from the acclimation sites. At the end of May all remaining fish are flushed into the river. Total juvenile spring chinook production in the first four years of this project was 389,273 for brood year 1997, 605,186 for brood year 1998, 758,252 for brood year 1999, and 838,174 for brood year 2000 (Berg, 2001).

\section{Sampling design}

This paper reports on early male maturation as part of a larger study examining developmental physiology of the first four brood years (BY 97-00) of hatchery reared spring chinook salmon. In this particular paper data are presented only from BY's 98-00. For BY 98 and BY 99 fish were sampled monthly or bi-monthly from September (1 year post-fertilization) to February at the Cle Elum Hatchery. Following transfer to the remote acclimation sites, fish were sampled bi-monthly from February to May at Clark Flat and at Jack Creek. Additionally, outmigrating wild and hatchery spring chinook were sampled from March to June at smolt bypass traps located at Roza Dam (Rkm 208) and Prosser Dam (Rkm 27) on the Yakima River. Finally, PIT-tagged wild and hatchery spring chinook, migrating from the Yakima River, were collected at the code-separator facility (operated by the Pacific States Marine Fisheries Commissionhttp://www.psmfc.org/pittag/Ptoc_OM/index.html) at John Day Dam (Rkm 348) on the Columbia River. At the Cle Elum Hatchery and the Jack Creek and Clark Flat acclimation sites 8 fish from each of 4 raceways (32 fish total) were collected on each sampling date. See figures for the number of fish sampled at Roza, Prosser, and John Day Dams. Collectively, these samples from fish at the hatchery, acclimation sites, and downstream dams are referred to as the BY 98 or BY 99 Physiological Monitoring.

Throughout the BY 98 and BY 99 Physiological Monitoring fish were sampled for length, weight, visual assessment of gender, and testicular enlargement (males), and plasma for measurement of 11-KT (primarily in males). Additionally, in January and from late March to June 2000 for BY 98 fish testes were collected for histological examination to confirm our supposition of spermatogenic activity in fish with visually enlarged testes. Since it was determined from BY 98 samples that 11-KT provided an earlier indication of the initiation of maturation than histological examination (see discussion below) no histology samples were collected from BY 99 fish. Finally, an extensive examination of the incidence of precocious male maturation at all three acclimation sites (Easton, Jack Creek, Clark Flat) was conducted during the hatchery's routine annual pathogen screening in mid-March for BY 99 and BY 00 fish. This element of the study, referred to as the BY 99 or BY 00 Maturity Screening, was conducted to examine a large number of fish at the latest date prior to the start of volitional migration. For the BY99 Maturity Screening we sampled 60 fish per raceway at each acclimation site (1080 fish total) for length, weight, gender, visual assessment of gonadal development, testes for histological examination, and plasma for 11-KT. For 
BY00 the same procedure was followed except no testes were collected for histological examination, but they were weighed on a microbalance to the nearest milligram for determination of gonadosomatic index: (GSI = gonad weight $(\mathrm{g}) /$ body weight $(\mathrm{g}) \times 100)$.

\section{Sample collection and analysis}

Fish were individually anesthetized in a buffered solution of $0.05 \%$ tricaine methanesulfonate (MS-222, Argent Chemical Laboratories, Redmond, WA), weighed to the nearest $0.1 \mathrm{~g}$ and measured to the nearest $1.0 \mathrm{~mm}$. Blood samples were collected from the severed caudal vessel into heparinized Natelson tubes (VWR Scientific), centrifuged for 3 minutes at $3000 \mathrm{~g}$, and stored frozen at $-80^{\circ} \mathrm{C}$ until analyzed by an enzyme-linked immunosorbant assay (ELISA) for 11-KT according to the method of Cuisset et al. (1994).

Gender and state of maturational development were assessed as follows: Immature females were identified by the gonad having an anterior thickening with a granular appearance, immature male fish by the gonad having a thin, clear, threadlike appearance with a diameter less than approximately $0.5 \mathrm{~mm}$ throughout the entire length and precociously maturing males by the gonad being opaque and having an anterior thickening of greater than approximately $1.0-1.5 \mathrm{~mm}$ (depending on date) and a smooth surface texture. During the BY 99 Maturity Screening males with testes of intermediate diameter were noted as non-distinguishable for subsequent categorization using plasma 11-KT levels. During the BY 00 Maturity Screening testes were categorized only as immature or mature.

For histological analysis testes were dissected and fixed in Bouin's fixative for 24 hours prior to storage in $70 \%$ ethanol. Fixed testes were dehydrated through an ascending series of ethanol and imbedded in paraplast, sectioned at $4 \mu \mathrm{m}$, and stained with hematoxylin and eosin. Testes were examined by light microscopy for stage of spermatogenesis according to criteria modified from Schulz (1984).

\section{Data analysis}

Plasma 11-KT levels and GSI measures were log transformed to aid in detection of bi-modality in the frequency distribution of the data. From both the BY 99 and BY 00 Maturity Screenings the mid-point between the lower and upper modes of the log 11-KT distributions was -0.1 or $0.8 \mathrm{ng} / \mathrm{ml}$ and this was used throughout the study as a threshold plasma 11-KT value below and above which fish were categorized as either immature or precociously maturing, respectively (see results for detailed description).

Throughout the BY 98 and BY 99 Physiological Monitoring log transformed plasma 11-KT values from all male fish and gender/maturity data from all fish were pooled for analysis according to source (hatchery or wild), sample location (hatchery, acclimation site, dam) and date as follows: Cle Elum Hatchery, Jack Creek and Clark Flat Acclimation sites before volitional migration, Jack Creek and Clark Flat Acclimation sites after the start of volitional migration, and hatchery and wild fish collected at Roza, Prosser and John Day Dams during smolt migration. Pooled gender data for hatchery and wild fish sampled at each of these sites and time periods were analyzed by Chi-squared Goodness of Fit (Zar 1984) to test for male: female ratios different from 50:50. 


\section{RESULTS}

\section{Screening for precocious maturation using plasma 11-KT levels}

The data from the BY 99 and BY 00 Maturity Screening are presented first to aid in understanding how male maturational condition was assigned throughout the BY 98 and BY 99 Physiological Monitoring. During the BY 99 Maturity Screening 1,080 fish were examined: $48.9 \%$ were visually assessed as females, $24.7 \%$ immature males, $18.6 \%$ precociously developing males, and $7.8 \%$ were males of uncertain maturational state. The frequency distribution of log transformed 11-KT levels from visually assessed immature and maturing males were distinctly bimodal (Figure $2 \mathrm{a}$ and $2 \mathrm{~b}$ ). 11-KT levels averaged $0.37 \pm 0.48 \mathrm{ng} / \mathrm{ml}$ and $4.2 \pm 0.15 \mathrm{ng} / \mathrm{ml}$ among visually assessed immature and maturing males, respectively. As indicated by the dashed line, the mid-point between modes was $\log 11-\mathrm{KT}-0.1$ or $11-\mathrm{KT} 0.8(\mathrm{ng} / \mathrm{ml})$. The frequency distribution of $\log 11-\mathrm{KT}$ levels from males of uncertain maturational state showed a distinct bi-modal distribution as well with $34.5 \%$ below and $65.5 \%$ above $0.8 \mathrm{ng} / \mathrm{ml}$ (Figure 2c).

During the BY 00 Maturity Screening 1,080 fish were examined: $48.3 \%$ were visually assessed as females, $34.3 \%$ immature males, $17.3 \%$ precociously developing males, and one male appeared to be a regressed precocious sub-yearling with white testes $(11-\mathrm{KT}=3.1 \mathrm{ng} / \mathrm{ml}$, GSI $=0.8 \%)$. As with the BY 99 Maturity Screening, the frequency distribution was distinctly bimodal (Figure 3a). 11-KT levels averaged $0.38 \pm 0.04 \mathrm{ng} / \mathrm{ml}$ and $4.7 \pm 0.22 \mathrm{ng} / \mathrm{ml}$ among visually assessed immature and maturing males, respectively. As indicated by the arrow, the mid-point between modes once again was $\log 11 \mathrm{KT}-0.1$ or $11-\mathrm{KT} 0.8(\mathrm{ng} / \mathrm{ml})$.

For BY 00 fish gonad weights were determined. The frequency distribution of $\log$ GSI also showed a bimodal distribution, with a mid-point between modes of log GSI -1.2 or GSI $0.06 \%$ (Figure $3 b$ ), however the separation between modes was less distinct compared to log 11-KT (Figure 3a). The regression between log 11-KT and log GSI was highly significant $\left(\mathrm{R}^{2}=0.7, p<0.0001\right)$ and showed a distinct clustering of points into lower and upper modes above and below the $0.8 \mathrm{ng} / \mathrm{ml}$ threshold (Figure 3c). The separate regressions for the lower and upper mode fish were also significant (lower $p=0.0004$, upper $p<0.0001$ ) however their $\mathrm{R}^{2}$ values were different (lower $\mathrm{R}^{2}=0.04$, upper $\mathrm{R}^{2}=0.4$ ). In general, the level of overlap between the upper and lower modes was much greater for log GSI than log 11-KT.

Based on the consistent pattern of bimodality for plasma 11-KT levels noted above, for both the BY 99 and BY 00 Maturity Screening and the BY 98 and 99 Physiological Monitoring $0.8 \mathrm{ng} / \mathrm{ml}$ was designated as the threshold for post hoc designation of male fish as either immature or maturing. Regardless of visual assessment at the hatchery and acclimation sites, fish with $11-\mathrm{KT}$ levels $\leq 0.8 \mathrm{ng} / \mathrm{ml}$ were designated as immature and those with levels $>0.8 \mathrm{ng} / \mathrm{ml}$ were designated as maturing. 11-KT levels from a sub-sample of 21 female fish averaged $0.10 \pm 0.02 \mathrm{ng} / \mathrm{ml}$ (data not shown). Finally, the $0.8 \mathrm{ng} / \mathrm{ml}$ threshold criterion was not applicable to fish sampled at downstream dams (see discussion below). 

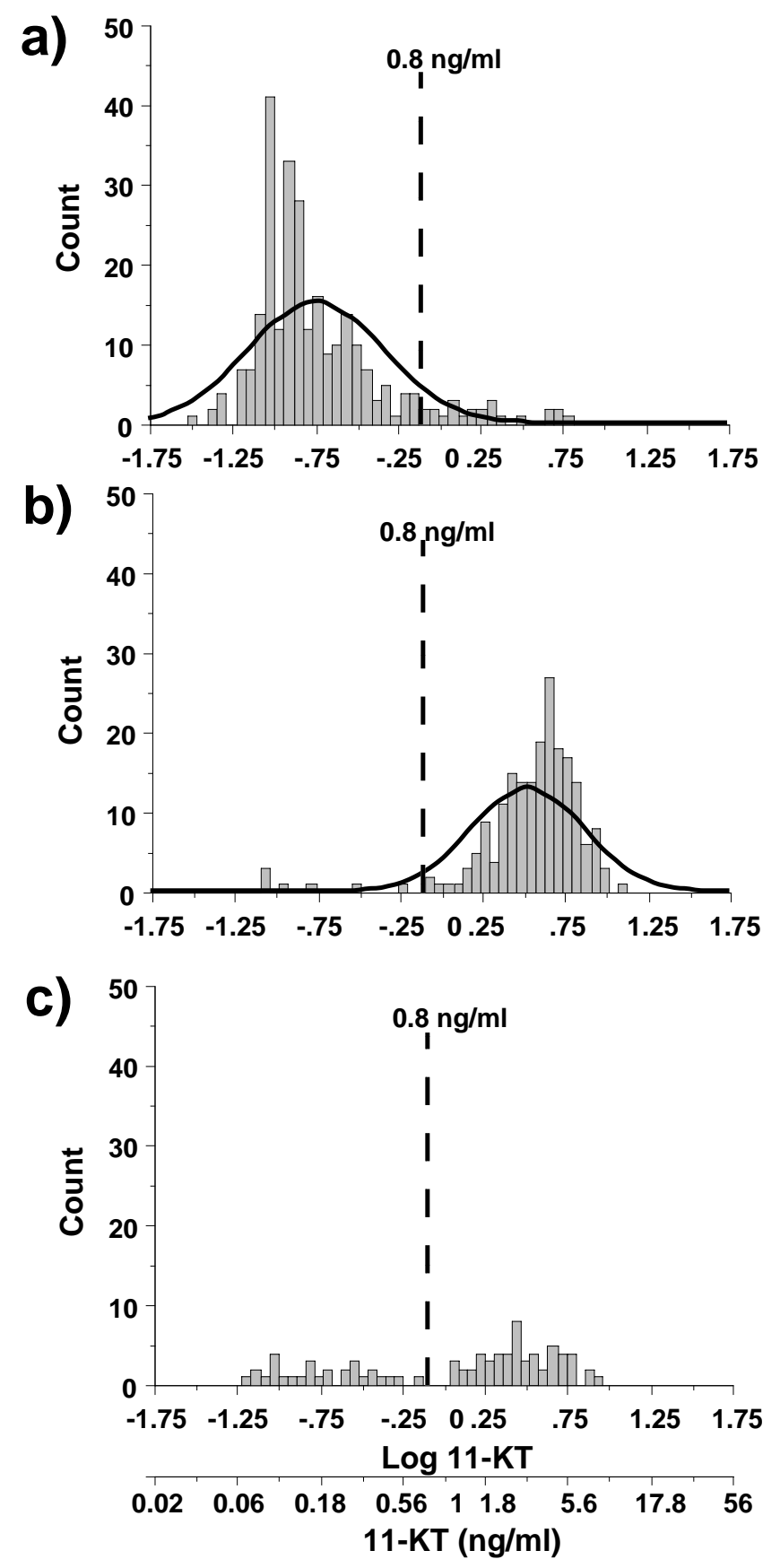

Figure 2. Frequency distribution of log transformed plasma 11-ketotestosterone levels in visually categorized immature males (a), precociously maturing males (b), and males of undetermined maturational state (c) during the BY99 Maturation Screening on 14 March, 2000. Dashed line indicates midpoint of $0.8 \mathrm{ng} / \mathrm{ml}$ between frequency distributions of immature and maturing fish. 


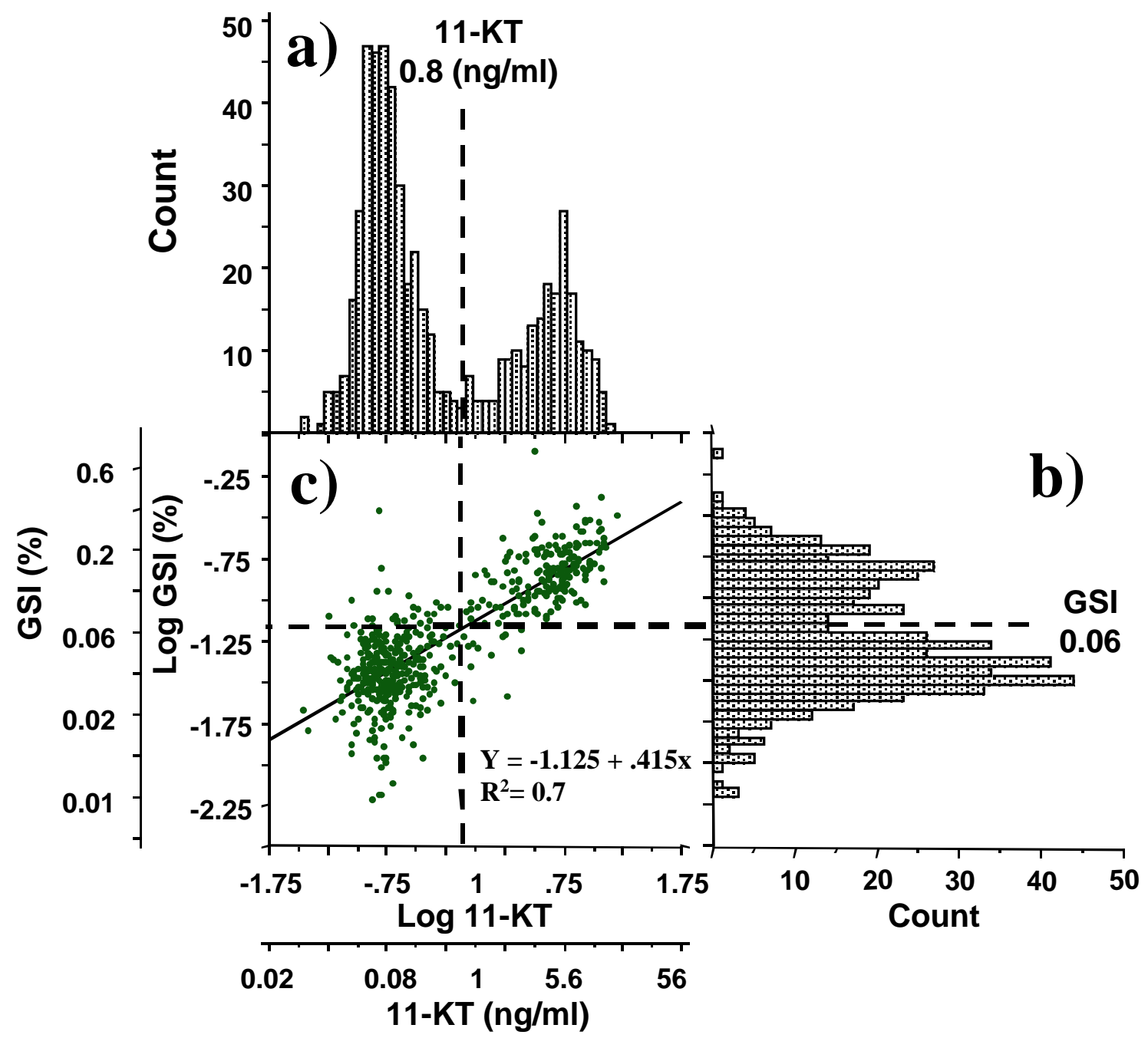

Figure 3. Frequency distributions of log transformed plasma 11-ketotestosterone (a) and gonadosomatic index (b) of male fish from the BY 00 Maturity Screening on 15 March 2002 and the regression between $\log 11-\mathrm{KT}$ and $\log$ GSI (c). Dashed lines indicate 11KT midpoint of $0.8 \mathrm{ng} / \mathrm{ml}$ and GSI midpoint of 0.06. Regression Equation: $\mathrm{Y}=0.415 \mathrm{x}-$ $1.125, \mathrm{R}^{2}=0.7, \mathrm{p}<0.0001$. 


\section{1-KT levels from the BY 98 and 99 Physiological Monitoring}

The frequency distribution of all log transformed plasma 11-KT levels from males sampled throughout the BY 98 and 99 Physiological Monitoring showed that at the Cle Elum Hatchery log 11-KT levels were generally unimodally distributed (Figures 4a and 5a). However, from February to March at both Jack Creek and Clark Flat Acclimation sites there was a distinct bi-modal distribution in 11-KT levels about the $0.8 \mathrm{ng} / \mathrm{ml}$ threshold (Figures 4b and 5b) and this was even further accentuated in samples collect from March to May after the start of volitional migration (Figures $4 \mathrm{c}$ and $5 \mathrm{c}$ ). The frequency distributions of log 11-KT levels from hatchery and wild males sampled from March to May at Roza dam were relatively bimodal about the $0.8 \mathrm{ng} / \mathrm{ml}$ threshold (Figures 4d and 5d) but at Prosser and John Day Dams were almost exclusively unimodal and below the $0.8 \mathrm{ng} / \mathrm{ml}$ threshold.

\section{Histology}

Testes histology was compared between males with relatively low $(<0.5 \mathrm{ng} / \mathrm{ml})$ and high (4.08-12.08 ng/ml) 11-KT levels at the Cle Elum Hatchery and the Jack Creek Acclimation site during the BY 98 Physiological Monitoring (Figure 6). The testes of visually assessed immature males consisted of mainly connective tissue, Sertoli cells, Leydig cells, and primitive type A and sometimes early type-B spermatogonia throughout the investigation at all sites (Figures 6a-e). However, by late-March at the acclimation sites, late-type B spermatogonial cysts, indicative of maturing fish, were observed in fish with enlarged testes (Figure 6h). In general, at the acclimation sites from late March to late-May there was consensus among maturational indicators such that males visually assessed as precociously maturing (data not shown) had elevated 11-KT levels above 0.8 $\mathrm{ng} / \mathrm{ml}$ (Figure 4 and 5) and the presence of late type-B spermatogonial cysts, spermatocytes and spermatids (Figures $6 \mathrm{~h}-\mathrm{j}$ ).

Histological examination of all testes samples from the BY 99 Maturity Screening (data not shown) showed results similar to that seen for the BY 98 Physiological Monitoring in mid-March (Figures $6 \mathrm{~b}$ and $\mathrm{g}$ ). Specifically, testes from visually assessed immature males and precociously developing males showed no obvious histological evidence of late type-B spermatogonia. Thus, overall prior to late-March, changes in 11KT levels appeared to precede histological changes in developing males.

Histological analysis of testes collected from visually assessed immature and precociously maturing fish at downstream dams (Figures 7a-f) did not always show the same correspondence among the three maturational indicators as that seen in April-May at the acclimation sites (Figures 4, 5 and 6). Specifically, many migrating fish (especially those collected at Prosser and John Day Dams) had low 11-KT levels $(<0.8 \mathrm{ng} / \mathrm{ml})$ regardless of whether they were visually assessed as immature or precociously maturing. However, histological examination of testes from these BY 98 fish consistently revealed

that fish visually assessed as precociously maturing possessed late type-B spermatogonia, and in many cases spermatocytes, spermatids, and spermatozoa (Figures 7d-f). Migrating fish that were visually assessed as immature (Figures 7a-c) had similar testicular development as the immature fish at the hatchery and acclimation sites (Figures 6a-e). So, at the hatchery and acclimation sites elevated 11-KT levels $(>0.8 \mathrm{ng} / \mathrm{ml})$ were 
a)

\section{b)}

Feb. 7 - Mar. 14 (before migration)

c)

Mar. 22 - May 22 (remaining in raceway during migration)

\section{d)}

Mar. 28 - May 3

e)

Apr. 28 - Jun. 6

f)

May 11 - Jun. 6 工
Cle Elum Hatchery
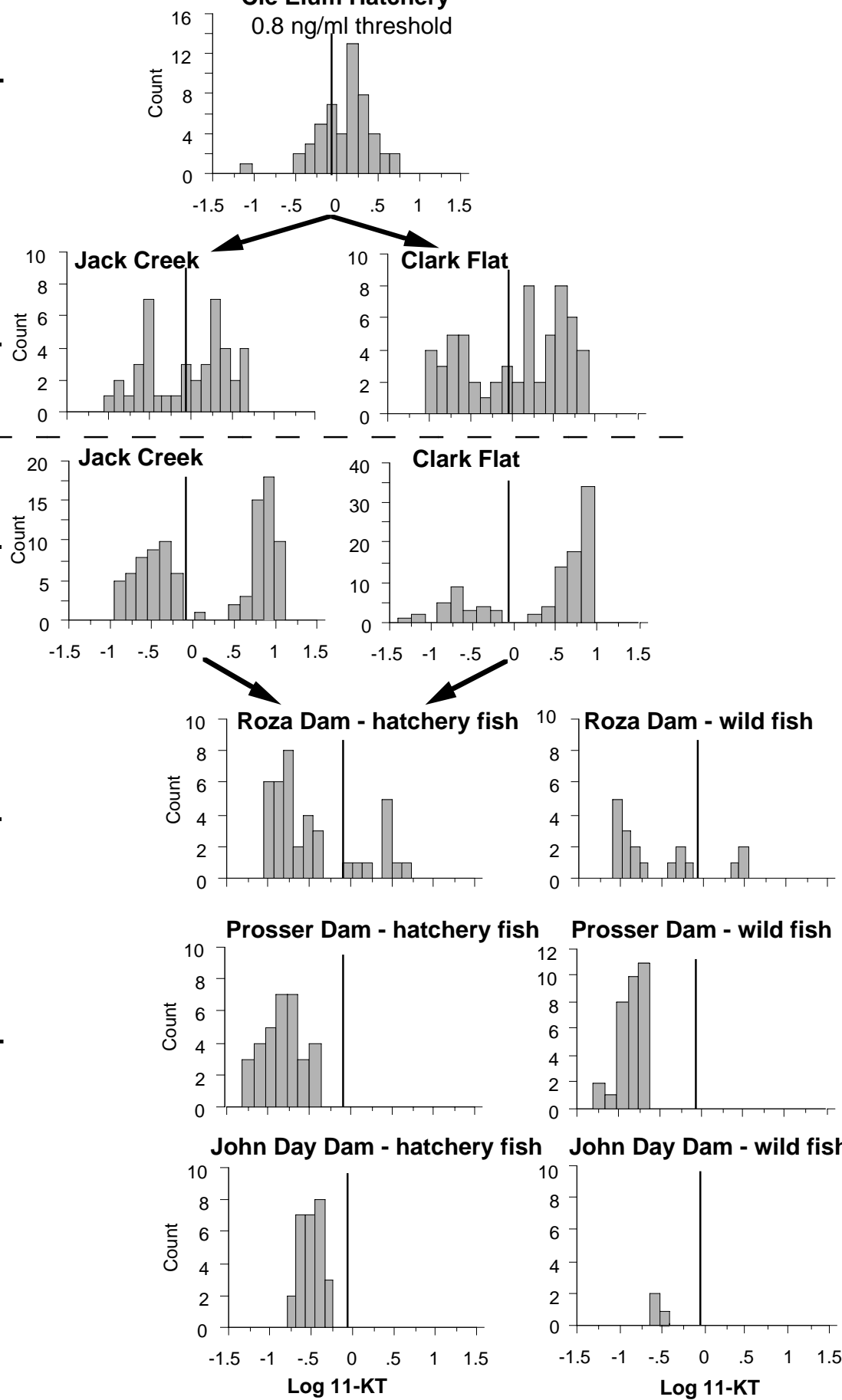

John Day Dam - wild fish

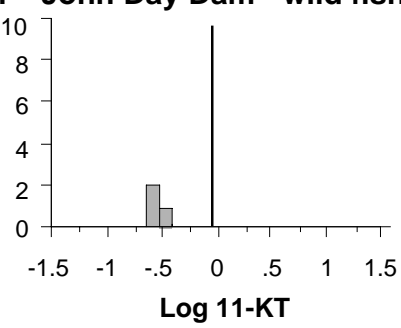

Figure 4. Frequency distributions of cumulative log transformed plasma 11ketotestosterone levels in BY98 hatchery male fish sampled over several dates at Cle Elum Hatchery (a), Jack Creek and Clark Flat Acclimation sites before (b) and after (c) the start of volitional migration, hatchery and wild fish sampled at Roza (d) and Prosser Dams (e) on the Yakima River and John Day Dam on the Columbia River (f). The 0.8 $\mathrm{ng} / \mathrm{ml} 11-\mathrm{KT}$ threshold is indicated by a vertical line all several graphs. 
a)

b)

Feb. 14 - Mar. 14-

(before migration)

c)

Apr. 4 - May 14 (remaining in raceway during migration)

d)

Apr. 19 - Apr. 25十

e)

May 1 - May 22 -

f)

May 15 - May 29_
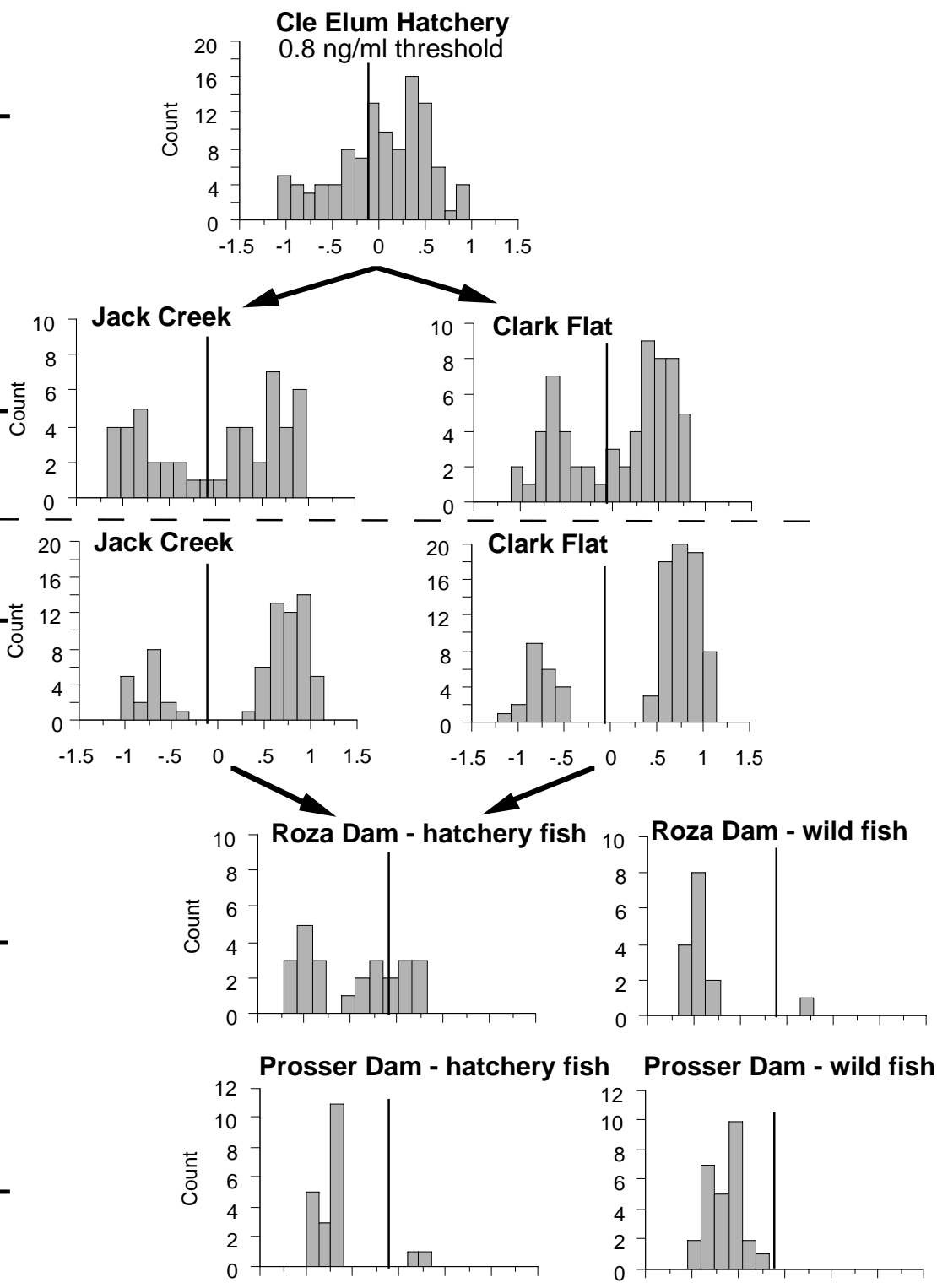

Prosser Dam - wild fish
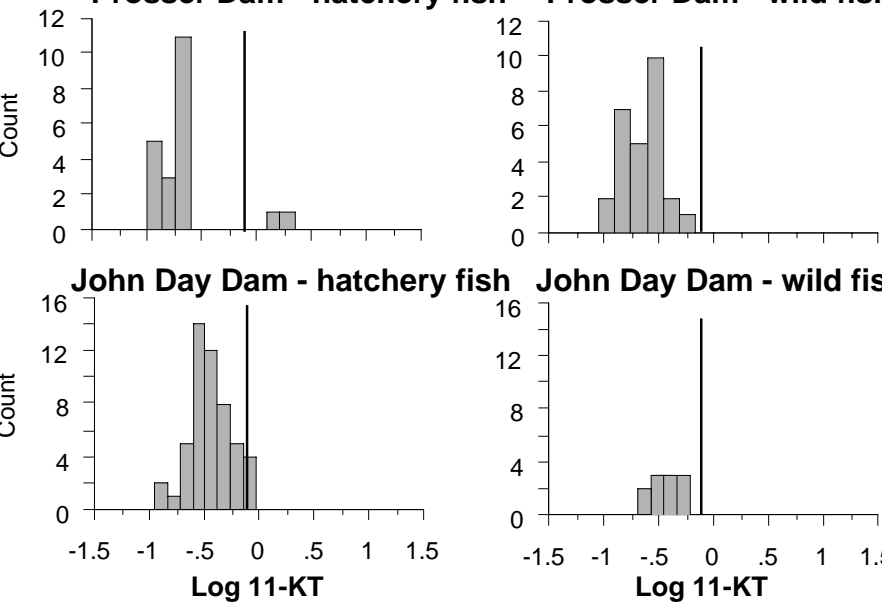

0

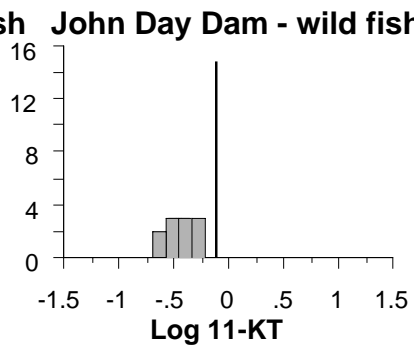

Figure 5. Frequency distributions of cumulative log transformed plasma 11ketotestosterone levels in BY99 hatchery male fish sampled over several dates at Cle Elum Hatchery (a), Jack Creek and Clark Flat Acclimation sites before (b) and after (c) the start of volitional migration, hatchery and wild fish sampled at Roza (d) and Prosser Dams (e) on the Yakima River and John Day Dam on the Columbia River (f). The 0.8 $\mathrm{ng} / \mathrm{ml} 11-\mathrm{KT}$ threshold is indicated by a vertical line on all graphs. 


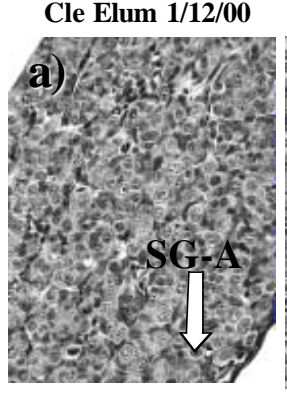

0.46 ng/ml 11-KT

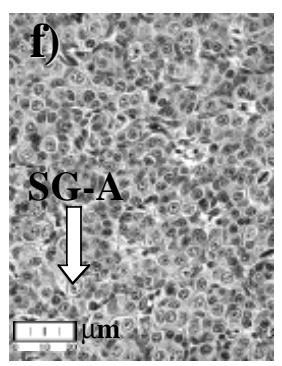

$4.08 \mathrm{ng} / \mathrm{ml} 11-\mathrm{KT}$

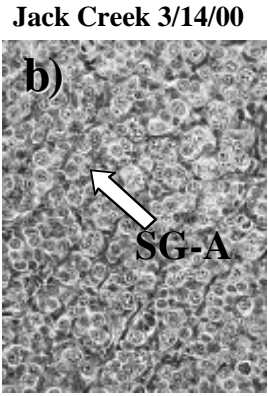

$0.15 \mathrm{ng} / \mathrm{ml}$ 11-KT

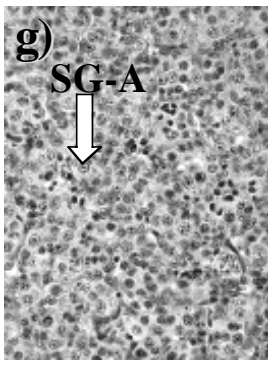

$6.88 \mathrm{ng} / \mathrm{ml} 11-\mathrm{KT}$

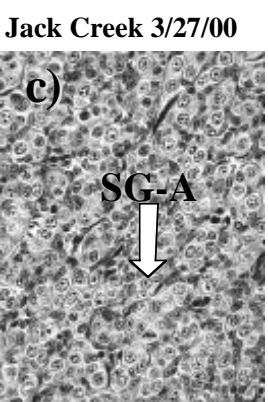

$0.2 \mathrm{ng} / \mathrm{ml}$ 11-KT

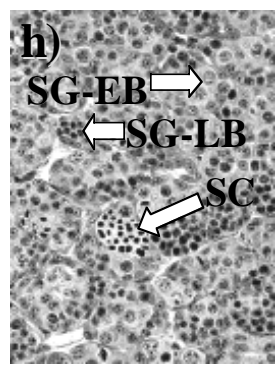

$6.0 \mathrm{ng} / \mathrm{ml} 11-\mathrm{KT}$

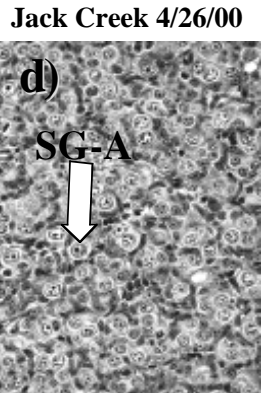

0.27 ng/ml 11-KT

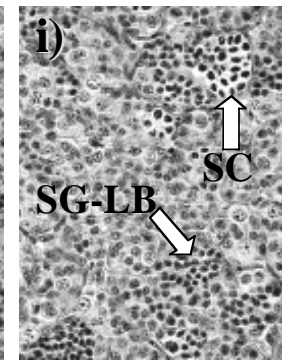

8.93 ng/ml 11-KT

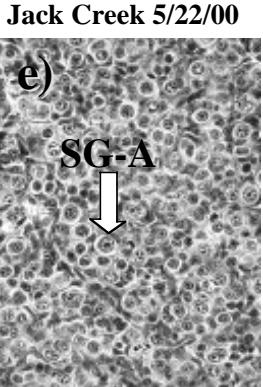

0.21 ng/ml 11-KT

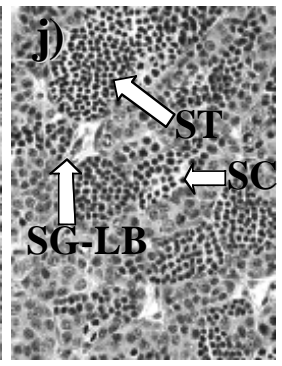

$12.08 \mathrm{ng} / \mathrm{ml}$ 11-KT

Figure 6. Light micrographs of testicular sections stained with hematoxylin and eosin from spring chinook salmon at Cle Elum Hatchery and Jack Creek Acclimation site with low (a-e) and high (f-j) plasma 11-ketotestosterone levels from 1 January to 22 May 2000 (b and g are from BY 99 Maturity Screening on 14 March 2001). SG-A (Type A spermatogonia), SG-EB (Early Type B spermatogonia), SG-LB (Late Type B spermatogonia), SC (Spermatocytes), ST (Spermatids). Magnification 40X. 


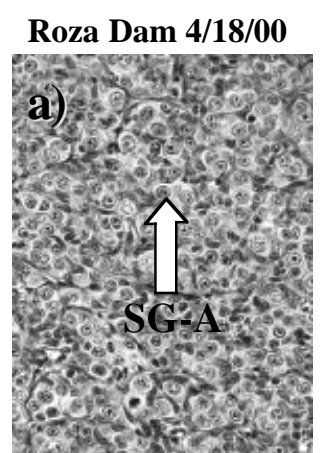

0.16 ng/ml 11-KT

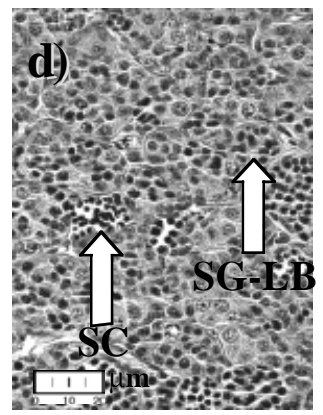

0.41 ng/ml 11-KT

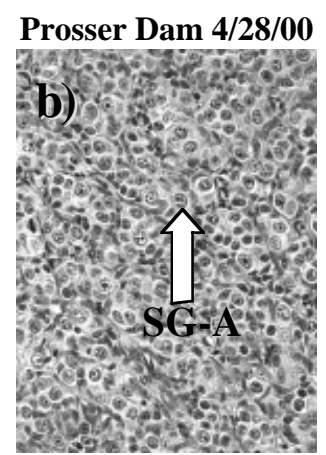

0.14 ng/ml 11-KT

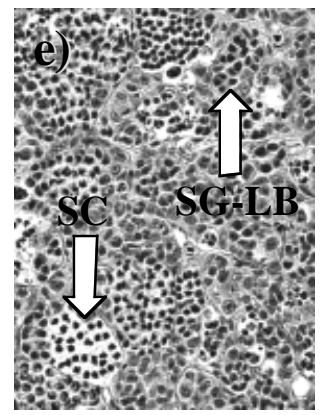

$0.43 \mathrm{ng} / \mathrm{ml}$ 11-KT

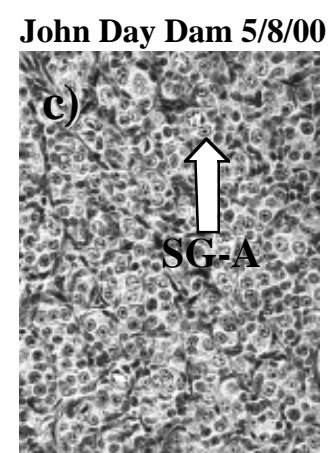

$0.29 \mathrm{ng} / \mathrm{ml} 11-\mathrm{KT}$

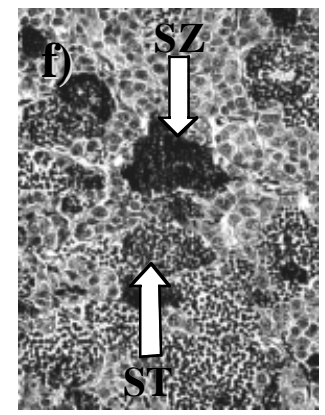

$0.40 \mathrm{ng} / \mathrm{ml}$ 11-KT

Figure 7. Light micrographs of testicular sections stained with hematoxylin and eosin from spring chinook salmon captured at Roza, Prosser, and John Day Dams that were visually assessed as immature (a-c) and precociously maturing (d-f). SG-A (Type A spermatogonia), SG-EB (Early Type B spermatogonia), SG-LB (Late Type B spermatogonia), SC (Spermatocytes), ST (Spermatids), SZ (Spermatozoa). Magnification 40X. 
considered the first indicator of precocious maturation followed by the presence of late type-B spermatogonia and visually detectable changes in testes size. However, once the fish began to migrate, plasma 11-KT levels did not always correlate with advanced testicular development. At downstream dams males were designated as precociously maturing primarily by visual assessment and, in cases where histological data were available (BY 98), by the presence of late type-B spermatogonia or later stages of spermatogenesis.

\section{Estimates of precocious maturation rates at the hatchery and downstream dams}

Using visual assessment of gender, the $0.8 \mathrm{ng} / \mathrm{ml} \mathrm{11-KT} \mathrm{threshold} \mathrm{at} \mathrm{the} \mathrm{hatchery,}$ and visual and histological assessment at the dams, gender and male maturation rates of BY 98 and BY 99 fish sampled during Physiological Monitoring were quantified (Figures 8a-f and 9a-f). Male maturation rates of hatchery fish ranged from 26-39\% at the Cle Elum Hatchery (October to January), $28-41 \%$ at the acclimation sites before volitional migration (February to March), 31-53\% at the acclimation sites after the start of migration (March to May), 14-40\% at Roza Dam (March to May), 3-8.1\% at Prosser Dam (April to June) and 1.8-10.8\% at John Day Dam (May-June). Among wild fish sampled at the dams maturation rates ranged from 2.9-8.4\% at Roza Dam, 0-2.9\% at Prosser Dam, and 0\% at John Day Dam.

The BY 99 and BY 00 Maturity Screening provided the most accurate (1080 fish sampled per year) estimates of the rate of precocious male maturation at the latest possible date before fish were released from the acclimation sites (Figure 10). For BY 99 (all acclimation sites combined) females accounted for $49 \%$, immature males $26 \%$, and precociously maturing males $25 \%$ of all fish sampled (Figure 10a). These rates of maturity were lower than those found at Clark Flat (41\%) and Jack Creek (33\%) before the start of volitional migration during the BY 99 Physiological Monitoring (Figure 8b), possibly a reflection of the larger sample size used during the Maturity Screening (CF$\mathrm{n}=360$ vs. 96 , JC-n=360 vs. 87 ). For BY 00 females accounted for $48 \%$, immature males $33 \%$, and precociously maturing males $19 \%$ of all fish sampled (Figure 10b).

During the BY 98 and BY 99 Physiological Monitoring the proportions of male and female hatchery and wild fish collected at the Cle Elum Hatchery, Jack Creek and Clark Flat Acclimation sites before and after volitional migration and at Roza, Prosser and John Day Dams were analyzed by Chi-squared Goodness of Fit to test for gender ratios different from 50:50 (Table 1). In both brood years, at the hatchery and acclimation sites, the gender ratio was either not significantly different from 50:50 or significantly favored male fish. By contrast, among hatchery fish collected at Roza, Prosser, and John Day Dams gender ratios were either not significantly different from 50:50 or significantly favored female fish, specifically at Prosser $\left(X^{2}=12.12\right)$ and John Day Dams $\left(X^{2}=13.14\right)$ for BY 98 and Prosser Dam $\left(X^{2}=6.45\right)$ for BY 99 . While the number of wild fish collected at some dams was relatively low, limiting statistical power to detect differences if they actually existed, it should be noted that the gender ratios were not significantly different from 50:50 at any of them. 


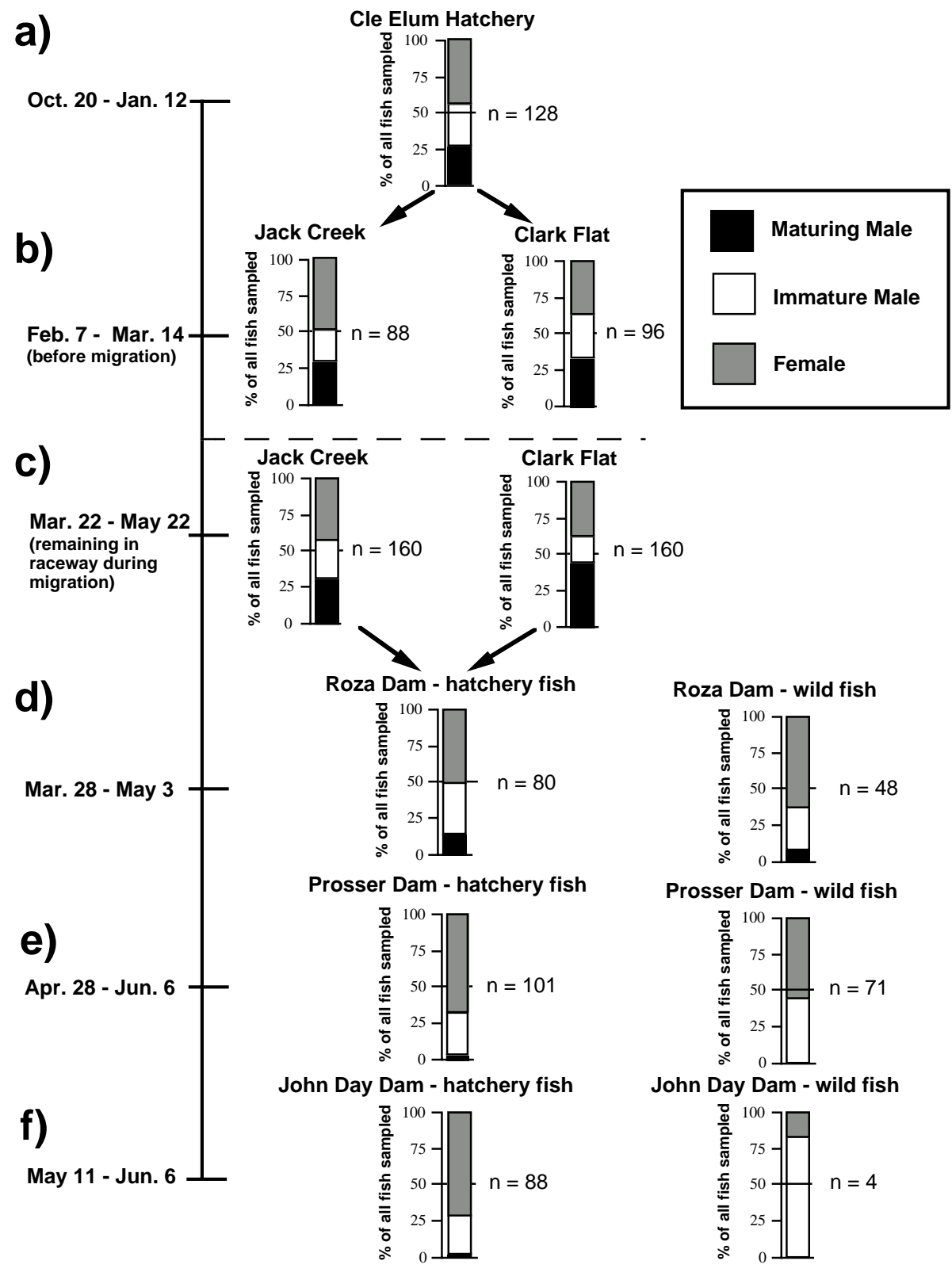

Figure 8. Proportions of precociously maturing male and immature male and female hatchery fish sampled over several dates at the Cle Elum Hatchery (a), Jack Creek and Clark Flat Acclimation Sites before (b) and after (c) the start of volitional migration, and hatchery and wild fish sampled at Roza (d) and Prosser Dams (e) on the Yakima River, and John Day Dam on the Columbia River (c) during the BY 98 Physiological Monitoring. At the hatchery and acclimation sites all male fish with 11-ketotestosterone levels greater than $0.8 \mathrm{ng} / \mathrm{ml}$ were designated as precociously maturing. At the dams maturing males were designated based on visual and histological analysis. After 14 March fish were allowed to volitionally emigrate from acclimation sites. Number of fish sampled at each site/time period is indicated for each histogram. 


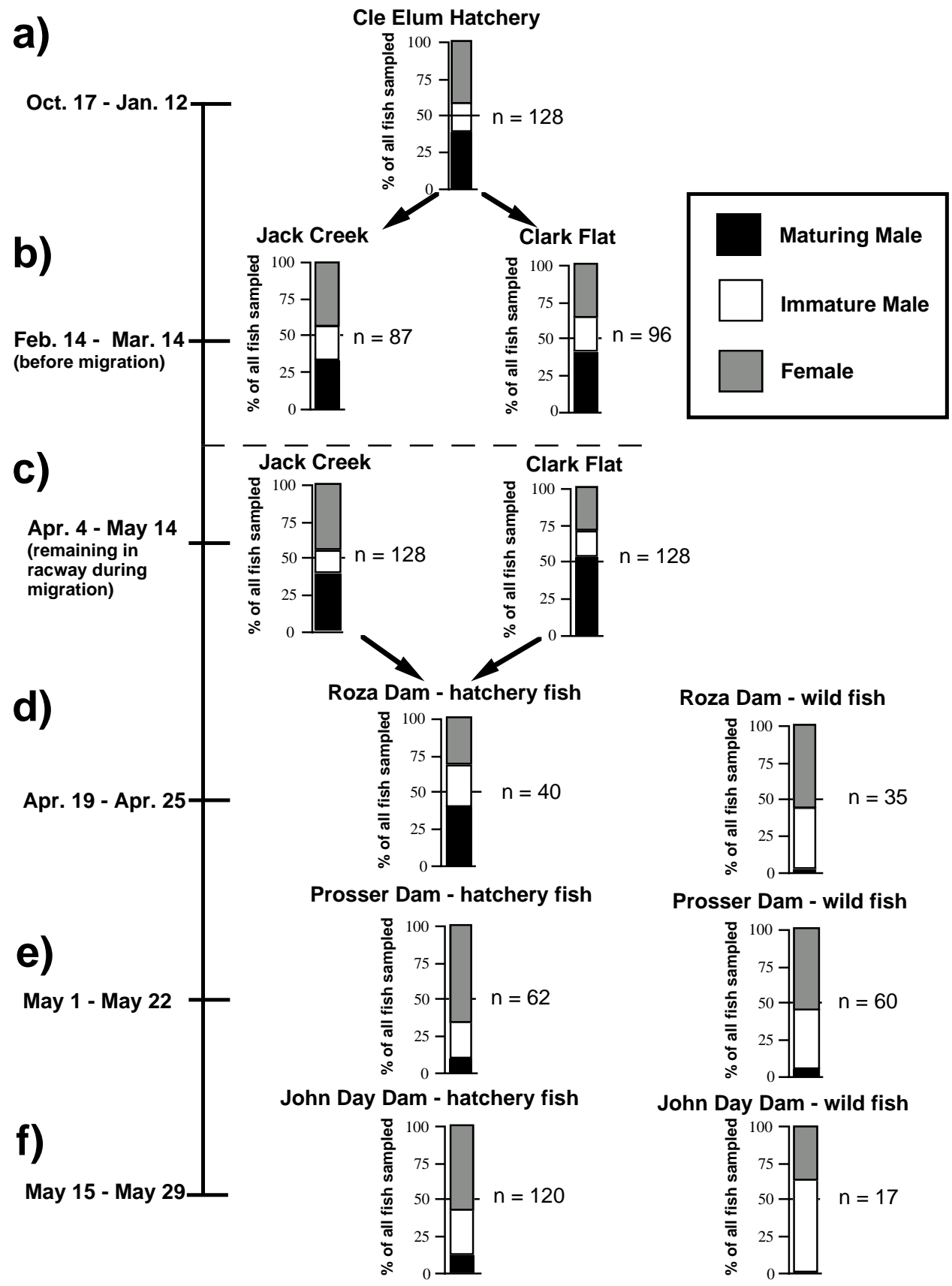

Figure 9. Proportions of precociously maturing male and immature male and female hatchery fish sampled over several dates at the Cle Elum Hatchery (a), Jack Creek and Clark Flat Acclimation Sites before (b) and after (c) the start of volitional migration, and hatchery and wild fish sampled at Roza (d) and Prosser Dams (e) on the Yakima River, and John Day Dam on the Columbia River (c) during the BY 99 Physiological Monitoring. At the hatchery and acclimation sites all male fish with 11-ketotestosterone levels greater than $0.8 \mathrm{ng} / \mathrm{ml}$ were designated as precociously maturing. At the dams maturing males were designated based on visual and histological analysis. After 14 March fish were allowed to volitionally emigrate from acclimation sites. Number of fish sampled at each site/time period is indicated for each histogram. 


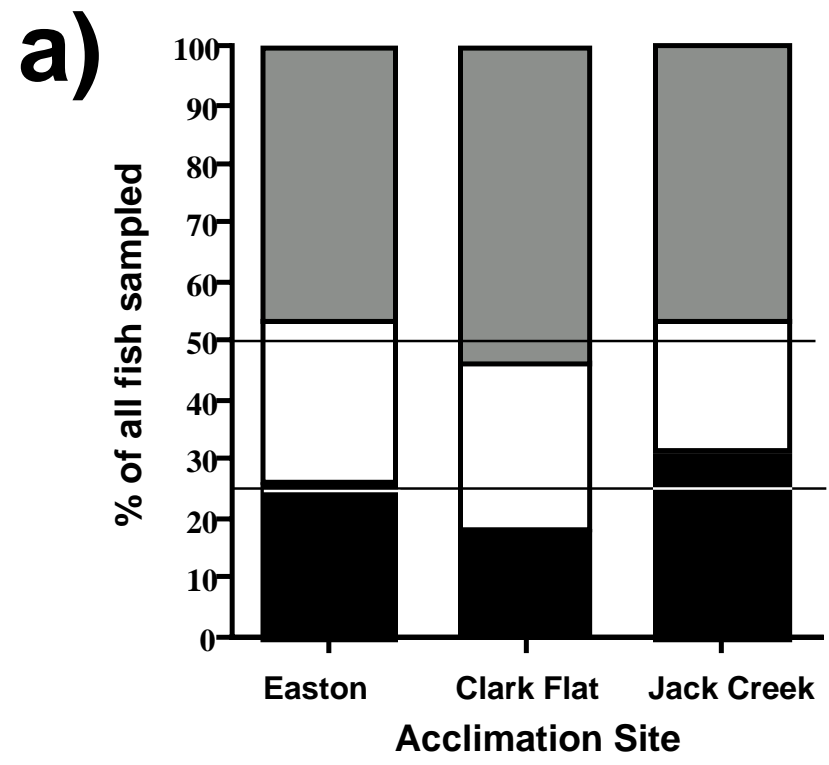

b)

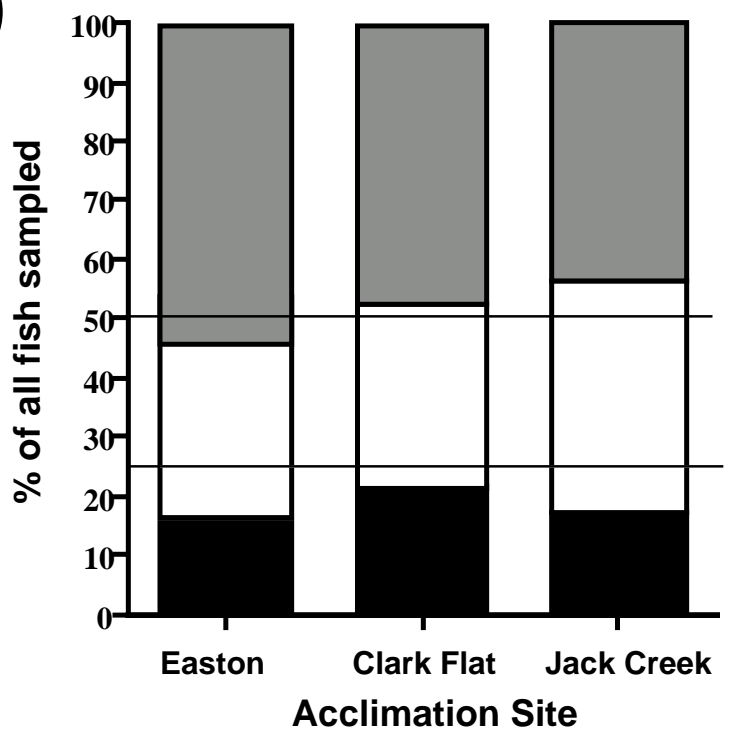

Figure 10. Proportions of precociously maturing male and immature male and female hatchery fish sampled on 14 March during the BY99 Maturity Screening (a) and on 15 March during the BY 00 Maturity Screening (b) at Easton, Jack Creek, and Clark Flat Acclimation Sites. All male fish with 11-ketotestosterone levels greater than $0.8 \mathrm{ng} / \mathrm{ml}$ were designated as precociously maturing. $\mathrm{N}=358-360$ fish at each site. 
Table 1. Chi-squared analysis of pooled gender data from hatchery and wild brood year (BY) 98 and 99 fish collected at the Cle Elum Hatchery, Jack Creek and Clark Flat Acclimation Sites, Roza, Prosser and John Day Dams. Asterisk indicates significant difference of underlined vales from 50:50 male to female ratio, $\alpha=0.05$.

\begin{tabular}{|c|c|c|c|c|c|c|}
\hline Site & $\begin{array}{c}\text { Hatchery or } \\
\text { Wild }\end{array}$ & Pooled Dates & $\begin{array}{c}\text { Total \# of } \\
\text { fish }\end{array}$ & \# Males & \# Females & $\mathrm{X}^{2}$ \\
\hline \multicolumn{7}{|l|}{ BY 98} \\
\hline Cle Elum Hatchery & Hatchery & $10 / 20,11 / 10,12 / 15,1 / 12$ & 128 & 72 & 56 & 2.00 \\
\hline Jack Creek Acc. Site & Hatchery & 2/7, 2/28, 3/14 (Before Vol. Release) & 88 & 44 & 44 & 0.00 \\
\hline Clark Flat Acc. Site & Hatchery & 2/7, 2/28, 3/14 (Before Vol. Release) & 96 & 61 & 35 & $7.04 *$ \\
\hline Jack Creek Acc. Site & Hatchery & $3 / 27,4 / 10,4 / 26,5 / 8,5 / 22$ (After Release) & 160 & 93 & 67 & $4.23 *$ \\
\hline Clark Flat Acc. Site & Hatchery & $3 / 27,4 / 10,4 / 26,5 / 8,5 / 22$ (After Release) & 160 & $\underline{100}$ & 60 & $10.0^{*}$ \\
\hline \multirow[t]{2}{*}{ Roza Dam } & Hatchery & & 80 & 39 & 41 & 0.05 \\
\hline & Wild & & 48 & 18 & 30 & 3.0 \\
\hline \multirow[t]{2}{*}{ Prosser Dam } & Hatchery & $4 / 28,5 / 4,5 / 11,5 / 23,6 / 6$ & 101 & 33 & 68 & $12.12 *$ \\
\hline & Wild & $4 / 28,5 / 4,5 / 11,5 / 23,6 / 6$ & 71 & 32 & 39 & 0.69 \\
\hline \multirow[t]{2}{*}{ John Day Dam } & Hatchery & $5 / 11,5 / 23,6 / 6$ & 88 & 27 & 61 & $13.14 *$ \\
\hline & Wild & $5 / 11,5 / 23$ & 4 & 3 & 1 & 1.0 \\
\hline \multicolumn{7}{|l|}{ BY99 } \\
\hline Cle Elum Hatchery & Hatchery & $10 / 17,11 / 15,12 / 12,1 / 12$ & 128 & $\underline{76}$ & 51 & $4.50 *$ \\
\hline Jack Creek Acc. Site & Hatchery & 2/14, 3/1, 3/14 (Before Vol. Release) & 87 & 50 & 37 & 1.94 \\
\hline Clark Flat Acc. Site & Hatchery & 2/14, 3/1, 3/14 (Before Vol. Release) & 96 & 62 & 34 & $8.17 *$ \\
\hline Jack Creek Acc. Site & Hatchery & 4/4, 4/18, 4/30, 5/14 (After Release) & 128 & 69 & 59 & 0.78 \\
\hline Clark Flat Acc. Site & Hatchery & 4/4, 4/18, 4/30, 5/14 (After Release) & 128 & 90 & 38 & $21.13^{*}$ \\
\hline \multirow[t]{2}{*}{ Roza Dam } & Hatchery & & 40 & $\underline{27}$ & 13 & $4.9^{*}$ \\
\hline & Wild & & 35 & 15 & 20 & 0.71 \\
\hline \multirow[t]{2}{*}{ Prosser Dam } & Hatchery & $5 / 1,5 / 15,5 / 22$ & 62 & 21 & 41 & $6.45^{*}$ \\
\hline & Wild & $5 / 1,5 / 15,5 / 22$ & 60 & 27 & 33 & 0.6 \\
\hline \multirow[t]{2}{*}{ John Day Dam } & Hatchery & $5 / 15,5 / 23,5 / 29$ & 120 & 51 & 69 & 2.7 \\
\hline & Wild & $5 / 15,5 / 23,5 / 29$ & 17 & 11 & 6 & 1.47 \\
\hline
\end{tabular}

\section{DISCUSSION}

In this investigation four different methods were used, individually or in combination, to determine if males were precociously maturing: simple visual assessment of testicular enlargement, histological detection of late type-B spermatogonia, GSI, and plasma 11-KT levels above $0.8 \mathrm{ng} / \mathrm{ml}$. Visual assessment of testes enlargement was a subjective, but simple and relatively accurate method (corroborated by histology and 11KT) for detecting precocious male maturation especially in April and May. Late type-B spermatogonia did not appear in maturing males until mid-April, several months after many males had 11-KT levels in excess of $0.8 \mathrm{ng} / \mathrm{ml}$ and a large proportion of the fish had migrated from the facility. Increases in plasma 11-KT levels prior to observable histological changes in testes of precociously maturing males were also reported by Shearer et al. (2000) and are not unexpected since reproductive steroids are produced by the less visible interstitial cells rather than the more visible gonial cells. The GSI was only determined in fish from the BY00 Maturity Screening in mid-March, when it provided relatively good separation between immature and maturing fish (corroborated by $11-\mathrm{KT}$ ). These very small gonads had to be weighed on a microbalance and its utility at earlier stages with even smaller gonads may be limited. Furthermore, there was significantly more overlap in GSI values between immature and maturing fish than observed with 11-KT. But, this method can provide a relatively reliable, quantitative, quick, and inexpensive method for assessing male maturation rates if sufficient numbers of fish are examined to detect bi-modality, especially in migrating fish where 11-KT levels may be suppressed. Overall, measurement of plasma 11-KT was the most accurate 
index of maturation because it was objective, quantitative, allowed for processing of large numbers of samples, and provided the earliest indication of spermatogenesis among the four indicators. It should be noted that there was a subjective element to this method in that we assume the $0.8 \mathrm{ng} / \mathrm{ml}$ level accurately indicates the threshold for precocious maturation because the value lies at the midpoint between these two modes.

The observation that elevated plasma 11-KT levels are one of the first endocrine indicators of the initiation of reproductive maturation in fish is not novel. Elevations in 11-KT above 1-2 ng/ml several months prior to spermiation have been shown in numerous salmonid species including rainbow trout (Schultz, 1984), 3 and 4 year-old maturing adult Atlantic salmon (Hunt et al. 1982; Stead et al. 1999), yearling precociously maturing Atlantic salmon (Stuart-Krogor et al. 1981; Mayer et al. 1990; Shrimpton and McCormick 2002), Arctic charr (Salvelinus alpinus) (Mayer et al. 1992), Brown trout (S. trutta) (Kime and Manning 1982), Japanese huchen (Amer et al. 2001) and spring chinook salmon (Shearer et al. 2000; 2002). Most of these studies developed seasonal plasma profiles for 11-KT from male fish that were either large enough to be serially sampled and later determined to be maturing or terminally sampled, but known to be maturing (i.e. re-maturing precocious Atlantic salmon or a population of males known to be maturing that year). In general, measurement of 11-KT was conducted to determine the timing of peak steroid levels during final maturation. Finally, in those studies that also measured 11-KT levels of immature males, plasma levels remained well below 1.0 $\mathrm{ng} / \mathrm{ml}$ throughout the period of spawning of the mature cohorts (Hunt et al. 1982; Mayer et al. 1990, 1992; Stead et al. 1999; Shrimpton and McCormick 2002; Shearer et al. 2002).

The novelty of this investigation, compared with previous efforts, was in the use of 11-KT to screen for the initiation of precocious maturation in a relatively large number of hatchery produced male fish. In fish sampled at the hatchery and acclimation sites 11KT levels provided a reliable metric for detection of precocious maturation. However, in migrating fish 11-KT levels decreased with both time and distance downstream regardless of whether the fish were visually and histologically determined to be precociously maturing. This discrepancy may be a function of increased hormone clearance with increased metabolic rate. The metabolic rate of a fish increases with increased water temperature and swimming activity (Schmidt-Nielsen 1985). The water temperature of the Yakima and Columbia Rivers increases throughout the spring and with distance downstream, ranging from $6-8{ }^{\circ} \mathrm{C}$ at Cle Elum to $11-15{ }^{\circ} \mathrm{C}$ in the lower Yakima River in April and May of a typical year and warmer in winters with low snow pack as was the case in 2001 for outmigrating BY 99 fish (U.S. Bureau of Reclamation Hydromet database). Manning and Kime (1985) showed that plasma levels of 11-KT in rainbow trout are decreased at $17^{\circ} \mathrm{C}$ compared to $12^{\circ} \mathrm{C}$. The water temperature at John Day Dam during late May 2001 was $16^{\circ} \mathrm{C}$ (Columbia River Data Access in Real Time).

Alternatively, high 11-KT levels may inhibit migration and perhaps only those maturing fish with low 11-KT levels were found downstream. In fact, high levels of androgens have been shown to suppress seawater tolerance in smolting Atlantic salmon (Lundqvist et al., 1989; Berglund et al. 1992). Finally, downstream migration and capture at hydroelectric dams is typically considered a stressful event for salmonids. Most stressful events induce secretion of the hormone cortisol (Schreck et al. 2001) that has been shown to suppress reproductive steroids in salmonids as well (Pickering et al. 1987; Pankhurst 
and Dedual 1994).

Despite the fact that 11-KT levels were of limited utility in detecting precocious maturation in fish at the dams, most migrating fish were collected in April and May; a time when clear visual and histological assessment of maturational state was possible. In summary, the most accurate method for estimating precocious male maturation was plasma 11-KT levels before migration and visual or histological assessment during migration. As noted above future studies of migrating fish will use GSI as a quantitative measure of precocious maturation.

A primary objective of this study was to determine the incidence of precocious male maturation in the Yakima hatchery population. The most accurate estimate was obtained using 11-KT levels from the BY99 and BY 00 Maturity Screening because we sampled over 500 male fish in each year at the latest possible date before the start of volitional migration. The female: male ratios were 49:51 (0.96) for BY 99 and 48:52 (0.92) for BY 00 suggesting that a representative census of the population, not favoring one gender, had been collected. Among all acclimation sites combined approximately $19-25 \%$ (avg. 22\%) of all fish (37-49\% of males) were estimated to be undergoing precocious maturation each year. Based on the total number of fish released and using an average of $22 \%$ precocious maturation, we estimate that this program has released approximately 85,640 precocious males for BY 97, 133,141 for BY 98, 166,815 for BY 99 and 184, 398 for BY 00.

Several lines of evidence suggest that a significant proportion of the precociously maturing males from this program do not migrate from the Yakima River Basin. Throughout the BY98 and BY99 Physiological Monitoring there was a general increase in the proportion of maturing males detected at the hatchery and acclimation sites on each sampling date over time (data for individual dates not shown). As more fish emigrated throughout the spring maturing males made up a greater proportion of fish sampled at the acclimation sites and a smaller proportion at downstream dams. Furthermore, nearly twice as many female as male fish were captured at Prosser and John Day Dams in three of four sampling periods over two years suggesting that a higher proportion of precocious males may be remaining in the headwaters (Table 1). At the dams only $4.8 \%$ and $10.8 \%$ of the hatchery fish sampled (from BY98 and BY99, respectively) were maturing males, collected primarily at Roza Dam. It is noteworthy that wild maturing males were also collected at the dams, but at a lower incidence of 3.3\% and 1.8\% of all fish sampled from BY98 and BY99.

Some of the maturing males that migrate past Roza Dam during spring turn around and move upstream a few months later. Yakama Nation Biologists collected 893 precociously maturing BY99 males migrating upstream between May 29 and September 10, 2001 (Avg. date of return July 20) at the Adult Collection and Monitoring Facility at Roza Dam during broodstock collection activities (unpublished data, Bill Bosch, Yakama Nation). During summer, precociously maturing males were easily distinguishable based on external characteristics and elastomer eye tags (Fork Length $-191 \pm 0.34 \mathrm{~mm}$, Weight $104 \pm 0.004 \mathrm{~g}$ ). In addition, 36 of the captured males (4\% of total) had PIT-tags allowing us to query the PITAGGIS database (Pacific States Marine Fisheries Commission) to examine their migratory history. The mature males exited the acclimation sites between March 19 and May 17 (avg. departure date April 18). The number of days between the fish exiting the acclimation site and their return upstream migration past Roza Dam 
ranged from 42 to 145 days (avg. 85.5 44.94 days). None of these PIT-tagged fish were intercepted at Prosser Dam on the lower Yakima River or any of the Columbia River dams downstream of the Yakima River confluence suggesting that they had not migrated far downstream before returning to the headwater reaches of the Yakima River.

Direct quantification of the incidence of yearling precocious maturation in wild Yakima spring chinook has not been conducted, but limited indirect evidence from other stocks would suggest that it is lower than the estimate of $44 \%$ of males found in the present investigation. In studies of wild spring chinook salmon from the Lemhi River of Idaho by Gebhards (1960) precocious development was prevalent in $2.6 \%$ of 3,443 salmon fingerlings in one study and the incidence of sub-yearlings and yearlings was $0.9 \%$ and $0.2 \%$, respectively from 1,020 fish examined in another study. According to Mullan (1992), precocious males constituted approximately $1 \%$ of 20,000 wild chinook salmon examined in tributary streams of the mid-Columbia River from 1983 to 1988. Two age-classes of wild precociously maturing spring chinook have been quantified on redds during spawning ground snorkel surveys in the Yakima River, but their proportion in the population overall is unknown (James et al. 1998). In contrast, Foote et al. (1991) reported that $56 \%$ of male parr matured as yearlings in a population of hatchery reared spring chinook form the Nicola River, British Columbia. In experiments conducted with this same stock, Clarke and Blackburn (1994) reported that 23-80\% of males matured as yearlings. Similarly, Mullan et al. (1992) reported that yearling maturation rates in various Columbia River hatchery stocks examined ranged from 11 to $24 \%$ of males. Finally, in two New Zealand hatcheries between 2.1 and $6.8 \%$ of fall-run male chinook salmon matured as yearlings (Unwin et al. 1999). Thus, it appears that hatchery rearing may promote precocious male maturation.

An uncharacteristically high incidence of precocious male maturation may have economic, management, ecological, and genetic consequences. Economically, high precocious maturation rates result in waste of resources invested in rearing fish that will not contribute to the fishery. At the resource management level, if these maturing fish are not detected prior to release, as is usually the case, they may significantly alter programmatic estimates for juvenile downstream and adult survival, in turn, impacting other future management decisions.

Among the potential ecological consequences of excess precocious males is skewing of the female: male ratios in favor of females on the spawning grounds among the anadromous adults and among all fish if mature yearlings do not survive in large numbers to spawn. Alternatively, if large numbers of mature yearlings survive to spawn they may saturate the spawning grounds of the wild fish. Another ecological concern is that excess precocious males may impact other native species by feeding on trout and salmon fry and by competing for limited habitat and food if they continue to feed through the summer rather than fast like returning anadromous spring chinook adults.

From a genetic perspective, work in Atlantic salmon with single locus DNA probes has shown that, despite there small size, mature parr may fertilize as much as $40 \%$ of the eggs within a population (Taggart and Ferguson 1990; Taggart et al. 1995; Fleming 1996). Furthermore, even though they produce a much smaller quantity of milt, recent work by Vladic et al. (2002) has suggested that compared with anadromous males, precocious parr produce physiologically superior sperm at a higher density that is capable of fertilizing an equal number of eggs to that of anadromous adults. Thus, the genetic 
contribution of these fish to subsequent generations, which have not experienced the same selection pressure as the anadromous males from the population, may be significant.

In light of the aforementioned concerns; what are the causes of high precocious male maturation rates and can they be controlled? It is important to stress that while age of maturation in salmon is subject to genetic control (Hankin et al. 1993; Heath et al. 1994) studies in coho (Silverstein and Hershberger 1992) and chinook salmon (Heath et al. 1994; Unwin et al. 1999) show low heritability for parr maturation. Previous studies strongly suggest that initiation of maturation in salmonids is significantly influenced by body size, growth rate, and body lipid level (Saunders et al. 1982; Rowe et al. 1991; Silverstein and Shimma 1994; Silverstein et al. 1997; 1998; Shearer and Swanson 2000; Shearer et al. 2000, 2002). Shearer and Swanson (2000) demonstrated that altering dietary lipid level could significantly vary maturation rates of wild source Yakima spring chinook. Thus, in the Yakima River stock, the genetic potential for a high incidence of early maturation certainly exists and rearing conditions can modulate that rate. These examples clearly demonstrate the very large environmental component to the "maturity decision" and suggest that hatchery practices may be altered to modulate maturation rates.

Controlling precocious maturation in salmon hatchery programs may be accomplished through manipulating growth. Studies, primarily in Atlantic salmon, have suggested that the spring period, proceeding autumn spawning, is a permissive period. If growth and energy stores are adequate, maturation progresses in fish that have initiated the process in the previous autumn. In fact, reduced feeding during the spring will reduce, but not prevent, the incidence of maturation in Atlantic (Rowe and Thorpe 1990, Herbinger and Friars 1992) and chinook salmon (Hopkins and Unwin, 1997). However, high growth rate during smoltification has been correlated with improved smolt quality, downstream migration, and smolt-to-adult return of spring chinook salmon (Beckman et al. 1999, 2000; Dickhoff et al.1995, 1997). Thus, reducing growth during the spring may retard early maturation in the precocious fish but be detrimental to successful smoltification of non-precociously maturing fish. The best strategy for preventing precocious male maturation may be prevention of initiation in the autumn one year prior to spawning.

Examination of the growth profiles of wild and hatchery spring chinook from the Yakima River support the contention that seasonal growth patterns in the hatchery environment may be conducive to high rates of precocious maturation. The growth profiles between naturally rearing Yakima spring chinook from BY 93 (Beckman et al. 2000) and that of BY 98 and BY 99 Yakima Hatchery fish are different (Figure 11). Wild Yakima River fish typically show high growth in the summer following emergence and reduced growth in the fall as temperature decreases. In contrast, despite some variation in absolute size between brood years, Yakima hatchery fish have moderate growth in the summer following emergence and very high growth in the fall. Based on studies noted above (Hopkins and Unwin 1997, Silverstein et al. 1997, 1998; Shearer et al. 2000, 2002) we hypothesize that the high autumn growth rate of the Yakima hatchery fish provides the energetic signal to initiate maturation in a significant proportion of the male fish. By altering growth rate during the critical summer-fall period, through manipulation of temperature and/or feed rate the incidence of precocious maturation may 


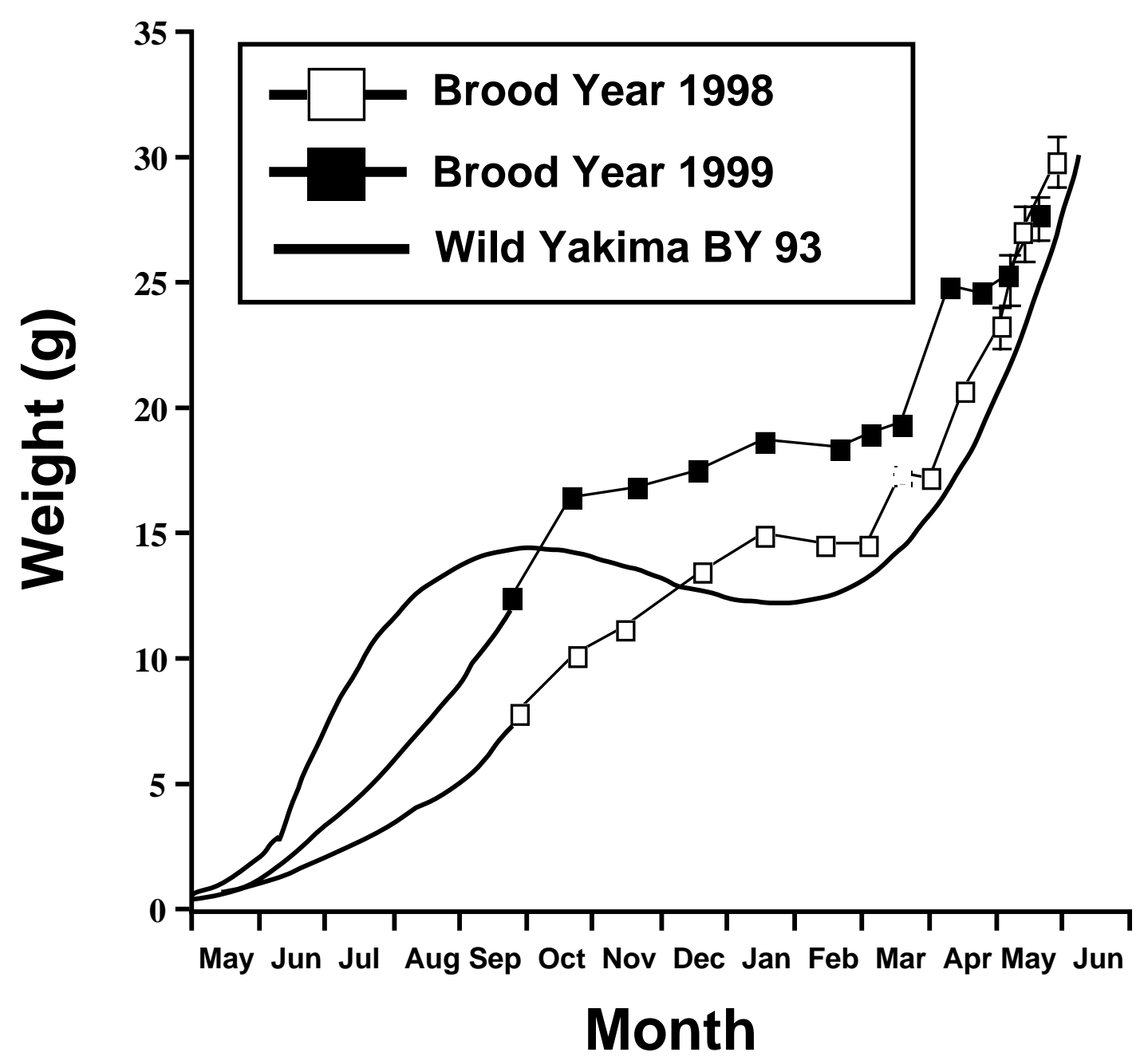

Figure 11. Comparison of body weight growth curves for BY 98 and BY 99 Yakima hatchery spring Chinook and BY 93 wild Yakima River spring Chinook (Beckman et al. 2000). Plot for growth in May for BY 93 wild fish and May to August for BY 98 and BY 99 Yakima hatchery fish was extrapolated from existing growth curves and drawn by hand. $\mathrm{N}=32$ fish per date for hatchery fish. 
be reduced. Studies to test this hypothesis are underway at the Cle Elum

Supplementation Research Facility in the summer of 2002.

In conclusion, this investigation has shed light on the prevalence of precocious maturation in a spring chinook salmon supplementation program. We estimate that during the period of study, approximately $44 \%$ of the males produced in this program underwent yearling precocious maturation. Precocious male maturation represents a natural life-history strategy in spring chinook salmon populations, but the hatchery environment may be potentiating this developmental pathway beyond natural levels. By drawing attention to this topic we are by no means singling out the Yakima Supplementation Program as unique among either production or supplementation hatcheries with regard to this issue. Rather, it was only through the significant monitoring efforts being employed by this program that the extent of this phenomenon at this hatchery was revealed. Other programs may have similar but, as of now, undetected levels of precocious male maturation. Fish in this program are grown at a comparable final size to wild Yakima spring chinook. But, recent studies suggest that energy reserves and growth rate rather than absolute size are more important determinants of life-history trajectory in salmonids. Future studies are needed to better quantify precocious maturation rates in this and other wild and hatchery stocks and rearing methods need to be developed to produce fish in hatchery programs with similar life-history attributes as their naturally reared cohorts.

\section{ACKNOWLEDGEMENTS}

This research was conducted in cooperation with Dave Fast, Bruce Watson, Joe Hoptowit, Gerald Lewis, Bill Bosch, John McConnaughey, and Leroy Senator (Yakama Nation, Toppenish, WA), Todd Pearsons, Steve Schroder, and Craig Busack (Washington Department of Fish and Wildlife, Olympia, WA) and Curt Knudsen (Oncorh Consulting, Olympia, WA). We thank the staff of the Cle Elum Supplementation and Research Hatchery, including Charles Strom and Jason Rau, for access to the fish and for assistance with collecting fish at the hatchery and acclimation cites. Assistance in sampling and laboratory analysis was provided by Brad Gadberry, Jon Dickey, Sherry Rehr, Nick Hodges (School of Aquatic and Fisheries Science, University of Washington, Seattle, WA), Andrew Dittman (National Marine Fisheries Service), and Paul Parkins (Pacific States Marine Fisheries Commission). We thank Briony Campbell (School of Aquatic and Fisheries Science, University of Washington) for comments on the original manuscript. Samples were collected during pathology screening with extensive assistance from Ray Brunson, Joy Everett, Chris Paterson, and Sonia Mumford (U.S. Fish and Wildlife Service, Olympia, WA). We also thank Dave Marvin, Rick Martinson and Greg Kovolchak (Pacific States Marine Fisheries Commission) for assistance in obtaining fish at John Day Dam. 


\section{LITERATURE CITED}

Aida, K., T. Kato, and M. Awaji. 1984. Effects of castration on the smoltification of precocious male masu salmon Oncorhynchus masou. Bulletin of the Japanese Society of Fisheries Science 50:565-571.

Amer, M.A., T. Miura, C. Miura, and K. Yamauchi. 2001. Involvement of sex steroid hormone in early stages of spermatogenesis in Japanese huchen (Hucho perryi). Biology of Reproduction 65:1057-1066.

Beckman, B. R., D. A. Larsen, C. Sharpe, B. Lee-Pawlak, and W. W. Dickhoff. 2000. Physiological status of naturally-rearing juvenile chinook salmon in the Yakima River: seasonal dynamics and changes associated with the parr-smolt transformation. Transactions of the American Fisheries Society 129:727-753.

Beckman, B.R., and ten coauthors. 1999. Growth, smoltification, and smolt-to-adult return of spring chinook salmon (Oncorhynchus tshawytscha) from hatcheries on the Deschutes River, Oregon. Transactions of the American Fisheries Society 128:1125-1150.

Berg, L. 2001. Yakima Subbasin Summary for the Northwest Power Planning Council. Available: www.cbfwa.org/files/province/plateau/subsum.htm.

Berglund, I., I. Mayer, and B. Borg. 1992. Effects of sexual maturation, castration and androgen implants on growth in one- and two-year old parr in a Baltic Atlantic salmon (Salmo salar L.) stock. Journal of Fish Biology 40:281-292.

Bernier, N. J., D. D. Heath, D. J. Randall, and G. K. Iwama. 1993. Repeat sexual maturation of precocious male chinook (Oncorhynchus tshawytscha) transferred to seawater. Canadian Journal of Zoology 71:683-688.

Borg, B. 1994. Androgens in teleost fishes. Comparative Biochemistry and Physiology 109:219-245.

Busack, , C. B. Watson, T. Pearsons, C. Knudsen, S. Phelps, and M. Johnston. 1997. Spring Chinook Supplementation Monitoring Plan. Report to Bonneville Power Administration, Publication. No. DOE/BP 64878-1. Portland, Oregon. (http://www.efw.bpa.gov/cgi-bin/efw/FW/publications.cgi) (Available from the Bonneville Power Administration, P.O. Box 3621, Portland, OR 97208).

Busack, C and A. Marshall. 1991. Genetic analysis of YFP chinook salmon stocks. Pages 2-45. in C. Busack, C. Knudsen, A. Marshall, S. Phelps, and D. Seiler. Yakima hatchery experimental design. Report to Bonneville Power Administration, Contract DE-B179-89BP00102. (Available from the Bonneville Power Administration, P.O. Box 3621, Portland, OR 97208). 
Clark, W.C. and J. Blackburn. 1994. Effect of growth on early sexual maturation in stream-type chinook salmon (Oncorhynchus tshawytscha). Aquaculture 121:95-103.

Columbia River Data Access in Real Time, (http://www.cbr.washington.edu/dart/dart.html).

Cuisset, B., P. Pradelles, D.E. Kime, E.R. Kuhn, P. Babin, F. Le Menn. 1994. Enzyme immunoassay for 11-ketotestosterone using acetylcholinesterase as label. Application to the measurement of 11-ketotstosterone in plasma of Siberian sturgeon. Comparative Biochemistry and Physiology 108:229-241.

Dellefors, C. and U. Faremo. 1988. Early sexual maturation in males of wild sea trout, Salmo trutta L., inhibits smoltification. Journal of Fish Biology 33:741-749.

Dickhoff, W.W., B. R. Beckman, D. A. Larsen, C. Duan, and S. Moriyama. 1997. The role of growth in the endocrine regulation of salmon smoltification. Fish Physiology and Biochemistry 17:231-236.

Dickhoff, W.W., B. R. Beckman, D. A. Larsen, C. V. W. Mahnken, C. B. Schreck, C. Sharpe, and W. S. Zaugg. 1995. Quality assessment of hatchery-reared spring chinook salmon smolts in the Columbia River Basin. Pages 292-302. in H. L. Schramm and R. G. Piper, editors. Uses and Effects of Cultured Fishes in Aquatic Ecosystems. American Fisheries Society, Bethesda, Maryland.

Flagg, T.A., and C.E. Nash, editors. 1999. A conceptual framework for conservation hatchery strategies for Pacific salmonids. U.S. Department of Commerce, NOAA Technical Memo. NMFS-NWFSC-38. Available: www.nwfsc.noaa.gov/pubs/tm/tm38/tm38.htm.

Fleming, I. A. 1998. Pattern and variability in the breeding system of Atlantic salmon (Salmo salar), with comparisons to other salmonids. Canadian Journal of Fisheries and Aquatic Sciences 55(Suppl. 1):59-76.

Fleming, I.A. 1996. Reproductive strategies of Atlantic salmon: ecology and evolution. Reviews in Fish Biology and Fisheries 6:379-416.

Foote, C. J., W. C. Clarke, and J. Blackburn. 1991. Inhibition of smolting in precocious male chinook salmon, Oncorhynchus tshawytscha. Canadian Journal of Zoology 69:1848-1852.

Gebhards, S.V. 1960. Biological notes on precocious male chinook salmon parr in the Salmon River drainage, Idaho. Progressive Fish Culturist 22:121-123.

Groot, C., and L. Margolis, editors. 1991. Pacific salmon life histories. University of British Columbia Press, Vancouver, B.C. 
Hankin, D.G., J.W. Nicholas, and T. W. Downey. 1993. Evidence for inheritance of age of maturity in chinook salmon (Oncorhynchus tshawytscha). Canadian Journal of Fisheries and Aquatic Sciences 50:347-358.

Heath, D.D., R. H. Devlin, J. W. Heath, and G. K. Iwama. 1994. Genetic, environmental and interaction effects on the incidence of jacking in Oncorhynchus tshawytscha (chinook salmon). Heredity 72:146-154.

Herbinger, C.M. and G. W. Friars. 1992. Effects of winter temperature and feeding regime on the rate of early maturation in Atlantic salmon (Salmo salar) male parr. Aquaculture 101:147-162.

Hopkins, C.L. and M. J. Unwin. 1997. The effect of restricted springtime feeding on growth and maturation of freshwater-reared chinook salmon, Oncorhynchus tshawytscha (Walbaum). Aquaculture Research 28:545-549.

Hunt, S.M.V., T. H. Simpson, and R. S. Wright. 1982. Seasonal changes in the levels of 11-oxotestosterone and testosterone in the serum of male salmon, Salmo salar L., and their relationship to growth and maturation cycle. Journal of Fish Biology 20:105-119.

Hutchings, J.A. and M. E. B. Jones. 1998. Life history variation and growth thresholds for maturity in Atlantic salmon, Salmo salar. Canadian Journal of Fisheries and Aquatic Sciences 55:22-47.

Idler, D.R., D. A. Horne, and G. B. Sangalang. 1971. Identification and quantification of the major androgens in testicular and peripheral plasma of Atlantic salmon during sexual maturation. General and Comparative Endocrinology 16:257-267.

Idler, D.R., P. J. Schmidt, and A. P. Ronald. 1960. Isolation and identification of 11ketotestoterone in salmon plasma. Canadian Journal of Biochemistry 38:1053-1054.

Iwamoto, R. N., B. A. Alexander, and W. K. Hershberger. 1984. Genotypic and environmental effects on the incidence of sexual precocity in coho salmon (Oncorhynchus kisutch). Aquaculture 43:105-121.

James, B.B., T.N. Pearsons, G. A. McMichael. 1998. Washington Department of Fish and Wildlife, Spring Chinook Salmon Interactions Indices and Residual/Precocial Monitoring in the Upper Yakima Basin, Report to Bonneville Power Administration, Contract No. 1995B164878, Project No. 9506409. (http://www.efw.bpa.gov/cgibin/efw/FW/publications.cgi) (Available from the Bonneville Power Administration, P.O. Box 3621, Portland, OR 97208).

Kato, F. 1991. Life histories of masu and amago salmon (Oncorhynchus masou and Oncorhynchus rhodurus). Pages 447-520. in C Groot and L. Margolis, editors. Pacific salmon life histories. University of British Columbia Press, Vancouver, B.C. 
Kime, D. E. and N. J. Manning. 1982. Seasonal patterns of free and conjugated androgens in the brown trout, Salmo trutta. General and Comparative Endocrinology 48:222-231.

Knudsen, C., S. Schroder, J. Rau, M. Johnston, C. Strom, and M. Hammlin. 2002. Monitoring phenotypic and demographic traits of Yakima River hatchery and wild spring chinook: Spawner traits. Pages 5-40. in C. Knudsen, editor. Reproductive Ecology of Yakima River hatchery and wild spring Chinook and Juvenile-to-Adult PIT Tag Retention Study. Annual Report to Washington Department of Fish and Wildlife 2001.

Lundqvist, H., B. Borg, and I. Berglund. 1989. Androgens impair seawater adaptability in smolting Baltic salmon (Salmo salar). Canadian Journal of Zoology 67:17331736.

Manning, N. J. and D. E. Kime. 1985. The effect of temperature on testicular steroid production in the rainbow trout, Salmo gairdneri, in vivo and in vitro. General and Comparative Endocrinology. 57:377-382.

Marshall, A.R., C. Smith, R. Brix, W. Dammers, J. Hymer, and L. LaVoy. 1995. Genetic diversity units and major ancestral lineages for chinook salmon in Washington. Pages 111-173. in C. Busack and J.B. Shaklee, editors. Genetic diversity units and major ancestral lineages of salmonid fishes in Washington. Washington Department of Fish and Wildlife Technical Report RAD 95-02. (Available from Washington Department of Fish and Wildlife, 600 Capital Way N., Olympia WA 98501-1091).

Mayer, I., H. Lundqvist, I. Berglund, M. Schmitz, M. Schulz, R. Schulz, and B. Borg. 1990. Seasonal endocrine changes in Baltic salmon, Salmo salar, immature parr and mature male parr. I. Plasma levels of five androgens, 17a-hydroxy-20bdihydroprogesterone, and 17 $\beta$-estradiol. Canadian Journal of Zoology 68:13601365 .

Mayer, I., M. Schmitz, B. Borg, and R. Schulz. 1992. Seasonal endocrine changes in male and female Arctic charr (Salvelinus alpinus). I. Plasma levels of three androgens, $17 \alpha$-hydroxy-20 $\beta$-dihydroprogesterone, and $17 \beta$-estradiol. Canadian Journal of Zoology 70:37-42.

Miura, T., T. Kobayashi, and Y. Nagahama. 1994. Hormonal regulation of spermatogenesis in the Japanese eel (Anquilla japonica). Pages 631-635. in K. G. Davey, editor. Perspectives in Comparative Endocrinology. National Research Council. Ottawa, Canada.

Mullan, J.W., A. Rockhold, and C. R. Chrisman. 1992. Life histories and precocity of chinook salmon in the Mid-Columbia River. Progressive Fish Culturist 54:25-28. 
Myers, J. M., and ten coauthors. 1998. Status review of Chinook salmon from Washington, Idaho, Oregon, and California. NOAA Technical Memorandum NMFS-NWFSC-35 (also available at http://www.nwfsc.noaa.gov/pubs/tm/tm35/index.htm).

Myers, R. A., J. A. Hutchings, and R. J. Gibson. 1986. Variation in male parr maturation within and among populations of Atlantic salmon, Salmo salar. Canadian Journal of Fisheries and Aquatic Sciences 43:1242-1248.

Myers, R.A. 1984. Demographic consequences of precocious maturation of Atlantic salmon (Salmo salar). Canadian Journal of Fisheries and Aquatic Sciences 41:13491353.

Nagahama, Y., S. Adachi, F. Tashiro, and E. G. Grau. 1982. Some endocrine factors affecting the development of seawater tolerance during parr-smolt transformations of the amago salmon, Oncorhynchus rhodurus. Aquaculture 28:81-90.

Pacific States Marine Fisheries Commission PITAGGIS database (http://www.psmfc.org/pittag/Data and Reports/PTAGIS DR-Main.html\#).

Pankhurst, N.W. and M. Dedual. 1994. Effects of capture and recovery on plasma levels of cortisol, lactate, and gonadal steroids in a natural population of rainbow trout. Journal of Fish Biology 45:1013-1025.

Pickering, A.D., T. G. Pottinger, J. Carragher, J. P. Sumpter. 1987. The effects of acute and chronic stress on the levels of reproductive hormones in the plasma of mature male brown trout, Salmo trutta L. General and Comparative Endocrinology 68:249259.

Power, G. 1986. Physical influences on age at maturity of Atlantic salmon (Salmo salar): a synthesis of ideas and questions. Pages 91-101. in D. J. Meerburg, editor. Salmonid age at maturity. Canadian Special Publication of Fisheries and Aquatic Sciences 89.

Rich, W. H., 1920. Early history and seaward migration of chinook salmon in the Columbia and Sacramento rivers. Bulletin of the United States Bureau of Fisheries 37:1-73.

Ricker, W. E. 1959. Additional observations concerning residual sockeye and kokanee (Oncorhynchus nerka). Journal of the Fisheries Research Board of Canada 16:897902.

Robertson, O.H. 1957. Survival of precociously mature king salmon male parr (Oncorhynchus tshawytscha (Juv.)) after spawning. California Fish and Game 43:119-130. 
Rowe, D. K., J. E. Thorpe, A. M. Shanks. 1991. The role of fat stores in the maturation in male Atlantic salmon (Salmo salar) parr. Canadian Journal of Fisheries and Aquatic Sciences 48:405-413.

Rowe, D.K., and J. E. Thorpe. 1990. Suppression of maturation in male Atlantic salmon (Salmo salar L.) parr by reduction in feeding and growth during spring months. Aquaculture 86:291-313.

Saunders, R. L., E. B. Henderson, and B. D. Glebe. 1982. Precocious sexual maturation and smoltification in male Atlantic salmon (Salmo salar). Aquaculture 28:211-229.

Schmidt, S. P., and E. J. House. 1979. Precocious sexual development in hatchery-reared and laboratory-maintained male steelhead trout (Salmo gairdneri). Journal of the Fisheries Research Board of Canada 36:90-93.

Schmidt-Nielsen, K. 1985. Animal Physiology: Adaptation and environment. Cambridge University Press. New York, N.Y.

Schreck, C.B., W. Contreras-Sanchez, and M. S. Fitzpatrick. 2001. Effects of stress on fish reproduction, gamete quality, and progeny. Aquaculture 197:3-24.

Schulz, R.W. 1984. Serum levels of 11-oxotestosterone in male and 17 $\beta$-estradiol in female rainbow trout (Salmo gairdneri) during the first reproductive cycle. General and Comparative Endocrinology 56:111-120.

Shearer, K.D. and P. Swanson. 2000. The effect of whole body lipid on early sexual maturation of 1+ age male chinook salmon (Oncorhynchus tshawytscha). Aquaculture 190:343-367.

Shearer, K.D., P. Swanson, B. Campbell, B.R. Beckman, P. Parkins, and J. T. Dickey. 2002. The effects of growth rate/size on the incidence of early sexual maturation in male spring chinook salmon (Oncorhynchus tshawytscha). Pages 14-35. in B.A. Berejikian, editor. Research on Captive Broodstock Programs for Pacific Salmon. Report to Bonneville Power Administration, Contract No. 199305600, Report DOE/B-00005277-2. (Available from the Bonneville Power Administration, P.O. Box 3621, Portland, OR 97208).

Shearer, K.D., P. Swanson, P., B. Campbell, B.R. Beckman, P. Parkins, and J. T. Dickey. 2000. The effects of growth rate and a low fat diet on the incidence of early sexual maturation in male spring chinook salmon (Oncorhynchus tshawytscha). Pages 38-76. in B.A. Berejikian, editor. Research on Captive Broodstock Programs for Pacific Salmon. Report to Bonneville Power Administration, Contract No. 199305600, Report DOE/BP-17895-1. (Available from the Bonneville Power Administration, P.O. Box 3621, Portland, OR 97208). 
Shrimpton, J.M. and S.D. McCormick. 2002. Seasonal changes in androgen levels in stream- and hatchery-reared Atlantic salmon parr and their relationship to smolting. Journal of Fish Biology 61:1294-1304.

Silverstein, J. T., and W. K. Hershberger. 1992. Precocious maturation in coho salmon (Oncorhynchus kisutch): estimation of the additive genetic variance. Journal of Heredity 83: 282-286.

Silverstein, J. T., H. Shimma, and H. Ogata. 1997. Early maturity in amago salmon (Oncorhynchus masu ishikawai): an association with energy storage. Canadian Journal of Fisheries and Aquatic Sciences. 54:444-451.

Silverstein, J.T. and H. Shimma. 1994. Effect of restricted feeding on early maturation in female and male amago salmon, Oncorhynchus masou ishikawae. Journal of Fish Biology 45:1133-1135.

Silverstein, J.T., K. D. Shearer, W. W. Dickhoff, and E.M. Plisetskaya. 1998. Effects of growth and fatness on sexual development of chinook salmon (Oncorhynchus tshawytscha) parr. Canadian Journal of Fisheries and Aquatic Sciences 55:23762382.

Stead, S.M., D. F. Houlihan, H. A. McLay, and R. Johnstone. 1999. Food consumption and growth in maturing Atlantic salmon (Salmo salar). Canadian Journal of Fisheries and Aquatic Sciences 56:2019-2028.

Stuart-Kroger, P.A.C., J. P. Sumpter, and J. M. Dodd. 1981. The involvement of gonadotrophin and sex steroids in the control of reproduction in the parr and adults of Atlantic salmon, Salmo salar L. Journal of Fish Biology 18:59-72.

Taggart, J. B. and A. Ferguson, A. 1990. Hypervariable minisatellite DNA single locus probes for the Atlantic salmon, Salmo salar L. Journal of Fish Biology 37:991-993.

Taggert, J. B., P. A. Prodohl, and A. Ferguson. 1995. Genetic markers for Atlantic salmon (Salmo salar L.): single locus inheritance and joint segregation analyses of minisatellite (VNTR) DNA loci. Animal Genetics 26:13-20.

Taylor, E. B. 1989. Precocial male maturation in laboratory-reared populations of chinook salmon, Oncorhynchus tshawytscha. Canadian Journal of Zoology 67: 1665-1669.

Thorpe, J.E. 1986. Age at first maturity in Atlantic salmon, Salmo salar: freshwater period influences and conflicts with smolting. in D.J. Meerburg, editor. Salmonid age at maturity. Canadian Special Publications in Fisheries and Aquatic Sciences 89. 
Thorpe, J.E. 1987. Smolting vs. residency: developmental conflicts in salmonids. American Fisheries Society Symposium 1:244-252.

Thorpe, J.E. 1991. Acceleration and deceleration effects of hatchery rearing on salmonid development, and their consequences for wild stocks. Aquaculture 98: 111-118.

Thorpe, J.E. and R. I. G. Morgan. 1980. Growth-rate and smolting rate of progeny of male Atlantic salmon parr, Salmo salar L. Journal of Fish Biology 17: 451-459.

Unwin, M.J., M. T. Kinnison, and T. P. Quinn. 1999. Exceptions to semelparity: Postmaturation, survival, morphology, and energetics of male chinook salmon (Oncorhynchus tshawytscha). Canadian Journal of Fisheries and Aquatic Sciences 56: 1172-1181.

Vladic, T. V., B. A. Afzelius, and G. E. Bronnikov. 2002. Sperm quality as reflected through morphology in salmon alternative life histories. Biology of Reproduction 66:98-105.

Zar, J.H. 1984. Biostatistical Analysis. Prentice Hall, Englewood Cliffs, NJ. 